This is the authors' final version, post peer-review, of an article published in European Urology doi.org/10.1016/j.eururo.2012.07.028. The definitive version is available from www.sciencedirect.com

\title{
Systematic review of perioperative and quality of life outcomes following surgical management of localised renal cancer
}

Steven MacLennan ${ }^{a}$, Mari Imamura ${ }^{a}$, Marie C. Lapitan ${ }^{b}$, Muhammad Imran Omar ${ }^{a}$, Thomas B. L. Lam ${ }^{a, c}$, Ana M. Hilvano-Cabungcal ${ }^{b}$, Pam Royle ${ }^{d}$, Fiona Stewart ${ }^{a, e}$, Graeme MacLennan $^{e}$, Sara J. MacLennan ${ }^{a}$, Philipp Dahm $^{f}$, Steven E. Canfield ${ }^{g}$, Sam McClinton $^{c}$, T.R. Leyshon Griffiths ${ }^{h}$, Börje Ljungberg ${ }^{i}$, James N'Dow ${ }^{a, c, *}$, UCAN Systematic Review Reference Group and the EAU Renal Cancer Guideline Panel

${ }^{a}$ Academic Urology Unit, University of Aberdeen, Aberdeen, United Kingdom

${ }^{b}$ Division of Urology, University of the Philippines-Manila, Manila, Philippines

${ }^{c}$ Department of Urology, Aberdeen Royal Infirmary, Aberdeen, United Kingdom

${ }^{d}$ Division of Health Sciences, University of Warwick, Warwick, United Kingdom

${ }^{e}$ Health Services Research Unit, University of Aberdeen, Aberdeen, United Kingdom

${ }^{f}$ Department of Urology, University of Florida, Gainesville, Florida, USA

${ }^{g}$ Division of Urology, University of Texas Medical School at Houston, Houston, USA

${ }^{h}$ Department of Urology, University Hospitals of Leicester NHS Trust, Leicester General Hospital, Leicester, United Kingdom

'Department of Surgical and Perioperative Sciences, Urology and Andrology, Umeå University, Umeå, Sweden

* Corresponding author. Professor James N'Dow, Academic Urology Unit, University of Aberdeen, $2^{\text {nd }}$ Floor, Health Sciences Building, Aberdeen AB25 2ZD, United Kingdom. Tel.: +44 1224 438130; Fax: +44 1224 438165. E-mail address: j.ndow@abdn.ac.uk

Keywords:

Localised renal cancer

Perioperative and quality of life outcomes

Radical nephrectomy

Adrenalectomy

Lymphadenectomy

Partial nephrectomy

Nephron-sparing surgery

Cryoablation

Radiofrequency ablation

HIFU

Systematic reviews

Meta-analysis 
Word count of text: 6020 (including Abstract)

Word count of abstract: 480

\section{ABSTRACT}

Context: For the treatment of localised renal cell carcinoma (RCC) uncertainties remain over the perioperative and quality of life (QoL) outcomes for the many different surgical techniques and approaches of nephrectomy. Controversy also remains on whether newer minimally invasive nephron-sparing interventions offer better QoL and perioperative outcomes, and whether adrenalectomy and lymphadenectomy should be performed simultaneously with nephrectomy. These non-oncological outcomes are important because they may have a considerable impact on localised RCC treatment decision-making. Objective: To systematically review all the relevant published literature comparing perioperative and QoL outcomes of surgical management of localised RCC (T1-2NOMO). Evidence Acquisition: Relevant databases including MEDLINE, Embase and the Cochrane Library were searched up to January 2012. Randomised or quasi-randomised controlled trials (RCTs), prospective observational studies with controls, retrospective matched-pair studies, and comparative studies from well defined registries/databases were included. The outcome measures were QoL, analgesic requirement, length of hospital stay, time to normal activity level, surgical morbidity and complications, ischaemia time, renal function, blood loss, length of operation, need for blood transfusion and perioperative mortality. The Cochrane risk of bias (RoB) tool was used to assess RCTs and an extended version was used to assess non-randomised studies (NRS). The quality of evidence was assessed using GRADE. Evidence Synthesis: 4580 abstracts and 380 full text articles were assessed. 29 studies met the inclusion criteria (7 RCTs and 22 NRSs). There were high risks of bias and low quality evidence for studies meeting the inclusion criteria. Principal Findings: There is good evidence indicating that partial nephrectomy results in better preservation of renal function and better QoL outcomes than radical nephrectomy regardless of technique or approach. Regarding radical nephrectomy, the laparoscopic approach has better perioperative outcomes than the open approach, and there is no evidence of a difference between the transperitoneal and retroperitoneal approaches. Alternatives to standard laparoscopic radical nephrectomy such as hand-assisted, robotic assisted or single-port techniques appear to have similar perioperative outcomes. There is no good evidence to suggest that minimally invasive procedures such as cryotherapy or radiofrequency ablation (RFA) have superior perioperative or QoL outcomes to nephrectomy. Regarding concomitant lymphadenectomy during nephrectomy, there were low event rates for complications and no definitive difference was observed. There was no evidence to base statements about concomitant ipsilateral adrenalectomy during nephrectomy. Conclusions: Partial nephrectomy results in significantly better preservation of renal function over radical nephrectomy. For tumours where partial nephrectomy is not technically feasible, there is no evidence that alternative procedures or techniques are better than laparoscopic radical nephrectomy in terms of perioperative or QoL outcomes. In making treatment decisions, perioperative and QoL outcomes should be considered in conjunction with oncological 
outcomes. Overall, there was a paucity of data regarding QoL outcomes, and when reported, both QoL and perioperative outcomes were inconsistently defined, measured or reported. The current evidence base has major limitations due to studies of low methodological quality marked by high risks of bias.

\section{Introduction}

Nephron-sparing surgery (i.e. partial nephrectomy) and other minimally invasive interventions such as cryoablation, radiofrequency ablation (RFA) and high-intensity focused ultrasound (HIFU) are alternative options to radical nephrectomy in the management of localised (T1-T2NOM0) renal cell carcinoma (RCC) [1-7]. Although the decision to undertake these procedures are usually oncologically driven, there is a definite need for better understanding of non-oncological outcomes associated with these competing interventions, as they influence treatment decision-making. Presently, various guidelines exist in relation to the various interventions for localised RCC $[1,5]$. However, it is important to recognise that many current urology guidelines recommendations are not based on systematic reviews of the evidence [8]. Consequently, a systematic review of current evidence is urgently needed in order to establish whether the non-oncological outcomes of all these competing interventions are comparable. Such a review should be performed with methodological rigour in assessing risks of bias and quality of evidence in a standardised and transparent way to highlight potential weaknesses in the evidence base and highlight areas for future research.

The objective of this systematic review was to compare the perioperative and quality of life (QoL) outcomes for all interventions relevant to the management of localised RCC. The oncological outcomes of the review are co-published in a separate article [9]. There is also a full report published online [10] with extra methodological information and data for oncological and surgical (non-oncological) outcomes.

\section{Evidence Acquisition}

\subsection{Search strategy}

The search was conducted in accordance with the principles outlined in the Cochrane Handbook of Systematic Reviews [11]. The databases searched were: MEDLINE (1950October 2010) and Embase (1980-October, 2010), Cochrane Library-all sections (Issue 4, 2010), Web of Science - with Conference Proceedings (1970-October 2010), and ASCO (American Society of Clinical Oncology) meeting abstracts (up to October 2010). The searches were not limited by language. Auto-alerts in MEDLINE and EMBASE were also run during the course of the review. Reference lists of relevant articles were also checked [10]. All abstracts and full-text articles were screened independently by two reviewers. Disagreement was resolved by discussion, and where no agreement was reached, a third 
independent party acted as an arbiter. In addition, an updated search was carried out to cover the period from October 2010 to January 2012.

\subsection{Types of study design included}

All relevant randomised or quasi-randomised controlled trials (RCTs) were included. Due to the small number of RCTs, we also included non-randomised studies (NRS). Prospective observational studies with controls, retrospective matched-pair studies, and comparative studies from well-defined registries/databases were also included. Studies with no comparator group (for example, case series); non-matched retrospective studies and chart reviews were excluded because of their higher risks of bias.

\subsection{Types of participants}

The study population was patients diagnosed with localised RCC based on CT scan or MRI, defined as clinical stage T1a-T2, NO, MO. Studies that reported pathological T3 cases were included so long as the clinical staging was T1-2 NO MO.

\subsection{Types of intervention}

The following interventions were compared:

- Radical nephrectomy

- Partial nephrectomy

- Laparoscopic surgery for radical or partial nephrectomy

- Hand-assisted laparoscopic surgery for radical or partial nephrectomy

- Robotic surgery for radical or partial nephrectomy

- Laparoscopic-assisted radiofrequency ablation (RFA)

- Laparoscopic-assisted cryoablation

- Laparoscopic-assisted high intensity focused ultrasound (HIFU)

A valid comparator was no intervention (i.e. active surveillance) or any of the specified interventions [10]. Ablative procedures performed percutaneously (such as percutaneous radiofrequency ablation) were excluded as they are not traditionally regarded as surgical treatment options.

The following interventions were also included in the review as additional procedures performed concurrently with either radical or partial nephrectomy:

- Complete regional (extended) lymphadenectomy

- Partial regional (limited) lymphadenectomy

- Adrenalectomy 


\subsection{Types of outcome measures}

The outcome measures of effectiveness are outlined below.

\section{Quality of Life Outcomes}

General health status measures e.g. Short Form 36 [12]

\section{Perioperative Outcomes}

- Surgical site infection

- Pneumonia

- Urinary tract infection

- Deep venous thrombosis

- Haemorrhage requiring transfusion

- Renal failure or decline in renal function

- Ischaemia time

- Overall morbidity

- Estimated blood loss

- Length of operation

- Need for blood transfusion

- Analgesic requirement

- Length of hospital stay

- Time to normal activity level

- Operative 30-day mortality rate

- Operative 90-day mortality rate

\section{Other Perioperative and Quality of Life Outcomes}

Non pre-specified outcomes judged important when performing the review.

\subsection{Assessment of risks of bias}

The risk of bias (RoB) in the included studies was assessed using the Cochrane Risk of Bias Assessment tool for RCTs [11]. A modified version of the RoB assessment tool was used in assessing NRS with the addition of further items (domains) to assess risk of bias through confounders [13].

A list of the four most important potential confounders (prognostic factors) for perioperative and quality of life outcomes identified a priori in consultation with content experts (drawn from the British Association of Urological Surgeons Section of Oncology and European Association of Urology Renal Cancer Guideline Panel) is given below: 
- Performance status

- Age

- Co-morbidity

- Ethnicity

The assessment of the pre-specified confounders is outlined in detail elsewhere [10].

\subsubsection{Assessment of the quality of evidence}

Out of the seven outcomes chosen for GRADE quality assessment in consultation with clinical content experts, two were oncological outcomes and five were non-oncological outcomes [10]. The five surgical and QoL outcomes are reported in this review and are listed as follows:

Critical:

- Condition-specific QoL

- Overall morbidity rates

- Time to normal activity level

Important:

- Analgesic requirement

- Need for blood transfusion

\subsection{Data analysis}

Outcomes were abstracted from included studies in the form of total numbers and proportions for dichotomous outcomes and total numbers, means and standard deviations (SD) for continuous outcomes. By default, dichotomous outcomes were analysed using fixed effect models to estimate relative risk (risk ratios) with $95 \%$ confidence intervals $(\mathrm{Cl})$. Continuous outcomes were analysed using a fixed effects model to estimate the (weighted) mean difference and $95 \% \mathrm{Cl}$. When using relative risks, if $95 \% \mathrm{Cl}$ in individual studies do not cross the line of no effect (i.e. one) then the result can be regarded as statistically significant at the $p=0.05$ level. When using mean difference, if $95 \% \mathrm{Cl}$ in individual studies do not cross the line of no effect (i.e. zero) then the result can be regarded as statistically significant at the $p=0.05$ level. A quantitative synthesis (meta-analysis) was performed for RCT data only where appropriate. The results of the limited number of meta-analyses undertaken for RCT data are mentioned in the text. Heterogeneity of data and high risks of bias arising from selection bias made meta-analysis inappropriate for NRS. The Forest plots show results of individual studies comparing the same interventions and reporting the same outcomes but pooled estimates are not provided for the methodological reasons outlined above. Where meta-analysis was not feasible, then a narrative synthesis is provided. 
Heterogeneity between studies was assessed using the $\chi^{2}$ test for heterogeneity and the $\mathrm{I}^{2}$ statistic [14]. Analysis was performed in the Cochrane RevMan software (version five).

Separate or subgroup analyses were planned but data were not sufficient to address any of these meaningfully [10].

\section{Evidence synthesis}

\subsection{Risk of Bias and Quality assessment of the included studies}

The study selection process is outlined in the PRISMA Diagram (Fig 1). There were 39 studies that met the inclusion criteria, and 28 (72\%) of which reported surgical outcomes, of which only 7 (25\%) were RCTs. The Cochrane RoB assessment can be viewed in Appendix 1. The additional non-randomised risk of bias assessment adjustment scores (outlined above) are displayed in Table 1 which reports baseline characteristics (all study designs) and adjustment scores (NRSs only).

\subsection{Comparisons of interventions results}

\subsubsection{Is surgery better than no surgery (i.e. active surveillance)?}

There were no studies that assessed this comparison in terms of perioperative and QoL outcomes.

\subsubsection{For radical nephrectomy, is the laparoscopic approach better than the open approach?}

Data were obtained from one RCT (Peng, 2006) [15] and two NRS (Gratzke, 2007 and Hemal, 2007) $[16,17]$. Mean length of hospital stay was significantly shorter in the laparoscopic radical nephrectomy group in all three studies [16], (Fig 2). There was no evidence of a difference in number of patients receiving a blood transfusion (Fig 3). Analgesic requirement was significantly lower in the laparoscopic radical nephrectomy arm in Hemal's study (Fig 4), and lower in the laparoscopic arm in Peng's study [15] but statistical significance is not estimable because no measure of spread is given [10]. Mean difference in convalescence time (weeks) was significantly shorter in the laparoscopic arm compared to the open arm in Hemal's study [17] (Fig 5). Mean difference in blood loss was significantly less in the laparoscopic arm in all three studies [15-17] (Fig 6). Surgical complications were marked by low event rates and very wide confidence intervals. There was no evidence of a difference in the rates of surgical site infection [16,17], pneumonia [16], haemorrhage [16], and postoperative mortality [10]. Mean difference in duration of operation (minutes) was significantly shorter in the open arm compared with the laparoscopic arm in Gratzke's [16] and Hemal's [17] studies, but there was no evidence of a difference in Peng's RCT [15] (Fig 7). 
Post-operative QoL scores were similar between groups in Gratzke's study [16] (Table 2). However, patients who had postoperative complications (regardless of the type of surgery) tended to have worse QoL scores compared with patients without complications [16]. The trend reached statistical significance in the general health domain $(p<0.05)$.

\subsubsection{For laparoscopic radical nephrectomy, are alternative approaches better than the standard 3-port transperitoneal approach?}

Two randomised studies (Desai 2005a; Nambirajan 2004) $[18,19]$ and one quasi-randomised study (Nadler 2006) [20] compared retroperitoneal and transperitoneal laparoscopic radical nephrectomy. All three trials provided information on operation time and length of hospital stay. Meta-analysis on operation time found a small difference favouring the retroperitoneal approach (Fig 7), although there was significant statistical heterogeneity $\left(I^{2}=89 \%\right)$. The reason for heterogeneity is unclear. There was no evidence of a difference in length of hospital stay between the two approaches (Fig. 2). It should be noted that the sample size is very small (11 in each arm) in Nadler's study [20]. Meta-analysis of data from the three trials on intra-operative blood loss found no significant difference between the two approaches (Fig 6). Other postoperative adverse events appear uncommon in the included studies [10] and there were no clear differences for these outcomes. Analgesic requirement did not differ between the groups (Fig. 4) whilst the results for time to normal activity revealed inconsistent findings (Fig. 5), (Fig. 8).

One quasi-RCT (Nadler, 2006) [20] and one NRS (Gabr 2009) [21] compared hand-assisted with standard (i.e. transperitoneal) laparoscopic radical nephrectomy. Length of hospital stay and time to non-strenuous activities (mean days) were significantly shorter for standard laparoscopic radical nephrectomy [20] [[21] (Figs 2 and 9), however, the sample size was small (11 patients in each arm). There was no evidence of a difference in other perioperative, recovery and mental health outcomes (Figs 4, 6, and 8)[20] [10,21], .

One quasi-randomised study compared hand-assisted laparoscopic versus standard retroperitoneal laparoscopic radical nephrectomy (Nadler) [20]. Duration of operation was significantly shorter in the hand-assisted compared to the retroperitoneal approach (Fig 7), but the sample size was small (11 in each arm). There was no evidence of a difference in other perioperative outcomes (Figs 2, 4, 6 and 8)

One prospective cohort study compared robotic versus laparoscopic radical nephrectomy [22]. There was no evidence of a difference in perioperative outcomes (Figs 2, 3 and 4)

Two observational studies [23,24] compared 'portless' (i.e. single port) and 3-port laparoscopic radical nephrectomy. One study [23] did not report adequate data to allow statistical comparison. There was no evidence of a difference in perioperative outcomes (Figs 2, 3, 6 and 7) [23,24].

\subsubsection{Is partial nephrectomy better than radical nephrectomy?}

\section{i. Open partial nephrectomy vs. open radical nephrectomy}

Two RCTs (D'Armiento, 1997; Van Poppel, 2007) [25,26], a prospective cohort study (Poulakis, 2003) [27], a database review (Butler, 1995) [28] and three matched pair studies 
(Shekarriz, 2002; Lee, 2007 and Gratzke, 2009) [16,29,30] were identified that compared various aspects of QoL and safety of open radical nephrectomy with open partial nephrectomy. In these studies tumour size inclusion criteria can be generally classified as small renal tumours. In Van Poppel's study [26], tumour size inclusion criteria was less than or equal to $5 \mathrm{~cm}$. Gratzke's study [16] does not give any information on tumour size but tumour stages T1-T2 were included. Shekarriz [30] limited inclusion criteria to less than $7 \mathrm{~cm}$, but did not stratify analysis by $<4 \mathrm{~cm}$ and $4-7 \mathrm{~cm}$ : the reported mean tumour sizes were close to $4 \mathrm{~cm}$ and the standard deviations imply that a proportion of the participants had tumours in the $4-7 \mathrm{~cm}$ range in both the radical and partial nephrectomy groups $(4.2 \mathrm{~cm}$ (1.9) vs. $3.8 \mathrm{~cm}(2.46))$. Poulakis [27] did not exclude patients with regard to tumour size, but did conduct subgroup analyses to reflect the $<4 \mathrm{~cm}$ and $4-7 \mathrm{~cm}$ controversy.

There was no evidence of a difference in length of hospital stay $[16,28,30]$ (Fig 2), number of patients requiring a blood transfusion $[16,28,30]$ (Fig 3), or mean blood loss [16,30] (Fig 6). The RCT by Van Poppel et al [26] showed no evidence of a difference in severe haemorrhage (i.e. blood loss over 1 L): RR 2.99 (95\%Cl 0.82, 10.92).

In general, complication rates were inconsistently reported in the NRSs, and event rates were low and do not favour one intervention over the other [10]. Shekarriz [30] found the mean duration of operation significantly longer for the open partial group but Gratzke [16] found no evidence of a difference (Fig 7).

Two studies reported QoL post-surgery for RCC. In Poulakis' prospective study [27] $(N=51)$, patients who underwent partial nephrectomy reported better scores, improving with time, in many aspects of QoL as measured by SF36 and EORTC QLQ-30. Those who underwent radical nephrectomy reported a higher degree of fear associated with living with only one kidney, but also less fear of recurrence (Poulakis 2003) [27] (Table 2). Regardless of intervention, patients with tumours $<4 \mathrm{~cm}$ in size and a normal contralateral kidney showed the highest QoL performance with return to their normal QoL scores after treatment (Poulakis, 2003) [27]. 72\% of Gratzke et al's (2009) [16] study group responded to the SF36 QoL questionnaire ( $N=34$ for open partial nephrectomy and 27 for open radical nephrectomy). The mean mental and physical component scores were similar between the groups (mental component: partial 44.5 vs. radical 48.3; physical component: partial 47.2 vs. radical 48 ) (Table 2 ) and the results were within one standard deviation of the age-matched norm, although patients who had higher complications rates had lower QoL scores.

Mean (range) warm ischemia time (WIT) for the partial nephrectomy arm in Gratzke's study [16] was 18 (9-39) minutes (Table 2). None of the other studies in this comparison reported WIT. Three studies consistently reported worse renal function after radical nephrectomy compared to partial nephrectomy $[26,28,29]$. The RCT by Van Poppel [26] reported significantly lower median creatinine level at follow up in the partial nephrectomy group than in the radical nephrectomy group $(1.29 \mathrm{mg} / \mathrm{dl}$ vs. $1.50 \mathrm{mg} / \mathrm{dl}$ respectively; $p<0.0001)$ (Table 2). Butler [28] found a significantly higher mean postoperative serum creatinine level compared with preoperative levels after radical nephrectomy (preoperative: $1.1(0.3) \mathrm{mg} / \mathrm{dL}$ vs. postoperative: 1.5 (0.4) mg/dL; preoperative: 97 (26) $\mu \mathrm{mol} / \mathrm{L}$ vs. postoperative: 133 (35) $\mu \mathrm{mol} / \mathrm{L}(\mathrm{p}=>0.001)$ ) but there was no evidence of a difference in the preoperative and postoperative serum creatinine levels after partial nephrectomy (preoperative: $1.3(0.4)$ $\mathrm{mg} / \mathrm{dL}$ vs. postoperative: $1.3(0.6) \mathrm{mg} / \mathrm{dL}$, preoperative: 115 (35) $\mu \mathrm{mol} / \mathrm{L}$ vs. postoperative: 
115 (53) $\mu \mathrm{mol} / \mathrm{L}$ ( $p=$ not significant)) (Table 2). A significantly greater proportion of patients in the radical nephrectomy group had impaired postoperative renal function (defined as serum creatinine $>1.6 \mathrm{mg} / \mathrm{dL}$ ) after controlling for diabetes, hypertension and age (data not shown) in the study by Lee [29].

\section{ii. Laparoscopic partial nephrectomy vs. Iaparoscopic radical nephrectomy}

A database review (Simmons 2009) [31] compared 35 laparoscopic partial nephrectomy and 75 laparoscopic radical nephrectomy cases in tumours larger than $4 \mathrm{~cm}$ over a five-year period (2001-2005). Mean (SD) WIT for the laparoscopic partial nephrectomy group was 37 (11) minutes (Table 2). There was a significantly greater decrease in the estimated GFR (decrease of 13 vs. $24 \mathrm{ml} / \mathrm{min}, \mathrm{p}=0.03$ ) in the laparoscopic radical nephrectomy group and there was a significantly greater proportion of patients with a two-stage increase in the Chronic Kidney disease (CKD) stage in the laparoscopic radical nephrectomy group ( 0 vs. $12 \%, p=<0.001$ ) (Table 2).

One database review (Dash, 2006) [32] was identified that compared partial and radical nephrectomy (by open or laparoscopic approach) in tumours $4-7 \mathrm{~cm}$ in size. The increase in post-operative mean creatinine was significantly smaller in the partial nephrectomy group (difference between means at three months: $0.23 \mathrm{mg} / \mathrm{dl} ; 95 \% \mathrm{Cl} 0.11-0.34, \mathrm{p}<0.01$, and at 6-12 months: $0.21 \mathrm{mg} / \mathrm{dl}, 95 \% \mathrm{Cl} 0.09-0.34, \mathrm{p}<0.01$ ) (Table 2).

\subsubsection{Which is the best approach to perform partial nephrectomy?}

\section{i. Laparoscopic partial nephrectomy (LPN) vs. open partial nephrectomy (OPN)}

Two database reviews (Gill 2007, Lane 2010) [33,34] and two matched-pair analyses (Marzalek 2009, Gong 2008) [35,36] compared laparoscopic versus open techniques of partial nephrectomy. Gong et al [35] found that length of hospital stay was significantly shorter in the LPN group (Fig 2). Gill et al [33] reported the same direction of effect but did not report a measure of spread so statistical significance could not be tested (Fig 2). There were significantly more blood transfusion events in the LPN group in Gill's study [33], but there was no evidence of a difference for Gong's [35] and Marszalek's [36] studies (Fig 3). Gong [35] reported significantly less mean blood loss in the LPN group (Fig 6). Gill et al [33] also reported less mean blood loss in the LPN group but did not report a measure of spread so statistical significance could not be tested (Fig 6). Postoperative pneumonia and UTI event rates were very low and showed no consistent findings. There were significantly more postoperative haemorrhages in the LPN group in Gill's study [33] but no difference in Gong's [35] and Marszalek's [36] studies [10]. There was no evidence of any differences between the groups in postoperative mortality [33,35], deep vein thrombosis (DVT) [35], or pulmonary embolism events $[10,35,36]$. Operative duration was significantly longer in the LPN group in Gong's study [35] (Fig 7). Gill [33] reported mean operative times of 201 vs. 266 minutes in the LPN versus OPN groups but did not report a measure of spread so statistical significance could not be tested.

WIT was significantly longer in the LPN arm compared with the OPN arm in Gill's study (mean [range] WIT 30.7 [4, 68] minutes for LPN vs 20.1 [4, 52] minutes for OPN; relative risk $1.69,95 \% \mathrm{Cl} 1.62,1.77 ; \mathrm{p}=<0.0001$ ) whilst controlling for age, clinical tumour size, 
contralateral kidney function and bilateral disease status (Table 2). Similarly, mean (SD) WIT was significantly longer in the LPN group compared with the OPN group in Gong's study (32.8 (10.6) vs. 20.5 (6.6) minutes). In Marszalek's study, median [IQR] warm ischemia time in the LPN group was 23 [19,27] minutes, compared with median [IQR] cold ischemia time in the OPN group of $31[24,45]$ minutes $(p=<0.001$ ) (Table 2$)$. However, the authors did not state the reason for comparing WIT against cold ischaemia time.

Decline in glomerular filtration rate (GFR) was significantly greater in the LPN group in the immediate postoperative period in Marszalek's study [36] $(8.8 \%$ vs. $0.8 \%$ decline, $p=$ $<0.001$ ), but the difference was not significant after a mean further follow-up of 3.6 years (10.9\% vs. $10.6 \%, p=0.8$ ) (Table 2 ). There was no evidence of a difference in postoperative change in creatinine between the LPN and OPN groups in Gong's study [35] (0.03 vs. 0.21 $\mathrm{mg} / \mathrm{dL}, \mathrm{p}=0.27$ ) and the lowest serum creatinine within 90 days of surgery showed no evidence of a difference in Gill's study [33] (1.18 vs. $1.42 \mathrm{mg} / \mathrm{dL}$ ) (Table 2). It is important to note that the evidence base for this comparison remains poor, with all studies suffering from the high risks of bias inherent in most NRS.

\section{ii. Robotic partial nephrectomy vs. laparoscopic partial nephrectomy}

Aron (2008) [37] compared robotic laparoscopic partial nephrectomy versus standard laparoscopic partial nephrectomy in a matched-pair analysis. There was no evidence of a difference in perioperative outcomes [10] nor in the estimated GFR between both groups at baseline or at three months postoperatively (Table 2). There was no evidence of a difference in mean (SD) WIT in the robotic laparoscopic partial nephrectomy arm (23 (6.6) minutes) compared with the laparoscopic partial nephrectomy arm (22 (10.8) minutes, $p=0.89$ ) (Table 2). However, there were very few patients in the study $(n=24)$ and patients were not randomly assigned.

\section{iii. Radiofrequency-assisted robotic clampless partial nephrectomy (RFRLPN) vs. laparoscopic partial nephrectomy}

Wu (2010) [38] reported a database review comparing patients who underwent standard laparoscopic partial nephrectomy and radiofrequency-assisted robotic laparoscopic partial nephrectomy (RFRCPN). In the robotic arm, the procedure involved the use of a novel radiofrequency ablation probe to achieve haemostasis without clamping the renal hilum. There was no evidence of a difference in adverse events [10] or postoperative renal function (Table 2). Mean (range) WIT in the laparoscopic partial nephrectomy group was 31 (0-52) minutes (Table 2).

\subsubsection{Are minimally invasive ablative procedures better than partial or radical nephrectomy?}

\section{i. Laparoscopic-assisted cryoablation vs. partial nephrectomy}

Two studies compared laparoscopic cryoablation with laparoscopic partial nephrectomy. One was a prospective NRS (Desai 2005b) [39] whilst the other was a matched-pair study (O'Malley 2007) [40]. There was no evidence of a difference in perioperative outcomes, recovery times, complication rates [39,40] (Figs 2, 3 and 5) or postoperative serum creatinine $[39,40]$ (Table 2). Mean (SD) WIT was 30.2 (8.5) minutes and 27.6 (6) minutes in 
the laparoscopic partial nephrectomy arms in Desai's and O'Malley's studies respectively (Table 2). Blood loss was significantly less in the laparoscopic cryoablation group $[39,40]$ (Fig 6). O'Malley [40] found that laparoscopic cryoablation was significantly quicker than laparoscopic partial nephrectomy but there was no evidence to suggest a difference in Desai's study [39] (Fig 7). However, these results should be interpreted cautiously as the indications for both procedures are likely to be different. For instance, partial nephrectomy is usually indicated for tumours of up to $4 \mathrm{~cm}$, whereas minimally invasive ablative procedures are usually reserved for tumours up to $3 \mathrm{~cm}$ only, and in patients unfit for partial nephrectomy [5]. Furthermore, as the reports are NRS, it is likely that the study populations are heterogeneous.

One other matched-comparison study compared laparoscopic cryoablation with open partial nephrectomy (Ko, 2008) [41]. Length of hospital stay was significantly shorter (Fig 2) and mean blood loss was significantly less (Fig 6) in the laparoscopic cryoablation group. There was no evidence of a difference in the number of patients requiring a blood transfusion or duration of operation (Figs 3 and 7).

\section{ii. Laparoscopic-assisted HIFU or RFA vs. radical or partial nephrectomy}

No eligible studies that compared laparoscopic-assisted HIFU or RFA against either partial or radical nephrectomy were identified.

\subsubsection{Does ipsilateral lymphadenectomy or ipsilateral adrenalectomy result in worse perioperative outcomes during partial or radical nephrectomy?}

A sub-group analysis of a large RCT was performed after obtaining the trial data (EORTC 30881; Blom 2009) [42]. The groups were comparable in terms of postoperative complications, although event rates were generally low. The commonest complications included bleeding (6.7\% vs. $4.6 \%$ ), embolism ( $2 \%$ vs. $0.4 \%$ ) and infection (5.1\% vs. $5.8 \%$ ) for complete lymph node dissection vs. no dissection respectively. The differences were not significant (Table 2); however, the subgroup analysis was underpowered because the trial was not designed to test this hypothesis.

There were no comparative studies that assessed perioperative or QoL outcomes for ipsilateral adrenalectomy at the time of partial or radical nephrectomy.

\section{Discussion}

\subsection{Principal Findings:}

The objective of this review was to determine the comparative perioperative and QoL outcomes of all surgical and minimally-invasive interventions used in the treatment of localised renal cancer. It is important to emphasise that treatment decisions are usually made on the basis of oncological outcomes. However, in instances where oncological outcomes are equivalent between interventions, then the emphasis shifts onto other outcomes, including perioperative and QoL outcomes. In addition, where there is uncertainty regarding oncological outcomes, any differences in perioperative outcomes 
should be interpreted accordingly. It is therefore important the findings from this review be considered in conjunction with the findings of our companion study [9].

For the comparison of techniques or approaches in performing radical nephrectomy, it can be concluded that laparoscopic radical nephrectomy is associated with shorter hospital stay, shorter convalescence time and lesser analgesic requirement compared with open radical nephrectomy. Given that laparoscopic and open radical nephrectomy appear to offer equivalent survival for localised renal cancers [9], if radical nephrectomy was indicated, it would seem prudent for the procedure to be performed laparoscopically. There was no evidence that alternative approaches, such as the retroperitoneal approach, or techniques, such as the hand-assisted, robot-assisted, or single port techniques, are better than the standard 3-port, transperitoneal approach. In practice, the choice of approach is also influenced by tumour location, patient's body habitus, previous intra-abdominal surgery and surgeon factors such as personal preference, technical skill and learning curve.

For the comparison of partial nephrectomy versus radical nephrectomy, the review found that partial nephrectomy results in better preservation of renal function and other QoL outcomes. This advantage is maintained regardless of choice of technique or approach of partial nephrectomy and this is consistent with data from other studies [43-46]. Consequently, we conclude that for tumours in which oncological outcomes have been shown to be equivalent amongst interventions, partial nephrectomy should be the preferred approach. Nevertheless, there is still a limited understanding of how the advantage in terms of preservation of renal function translates to long term morbidity or disease-specific mortality, including cardiovascular-related mortality [47]. In terms of how partial nephrectomy should be performed, it remains unclear if a laparoscopic approach offers better perioperative or QoL outcomes than an open approach. Lastly, in considering the potential benefits of nephron-sparing surgery in terms of preserving renal function, an important factor to bear in mind is ischaemia time, which should be minimised. However, notwithstanding the study limitations, in this review we found that WIT of approximately 30 minutes did not appear to compromise renal function in comparison with shorter WIT.

With regard to how minimally invasive ablative procedures compare with either partial or radical nephrectomy, data was available for laparoscopic-assisted cryoablation only. The studies reported different non-oncological outcomes such as blood loss and recovery time, but uniformly had high risks of bias, making definitive conclusions problematic. The absence of comparative studies for other laparoscopic-assisted ablative procedures such as RFA and HIFU was noteworthy. Consequently, until more robust and high quality comparative data become available, no minimally invasive ablative procedures can be considered superior to nephrectomy for perioperative or QoL outcomes. As such, evidence-based decision making for utilizing these techniques should be made based on oncological outcomes. It is important to note that presently there is considerable uncertainty with regard to the impact of these minimally invasive ablative procedures on oncological outcomes $[9,48]$, and these interventions should not be considered oncologically superior nor equivalent to either radical or partial nephrectomy. Therefore, it would be difficult to justify such novel treatment except for patients in whom surgery is inappropriate. 
This review found no statistically significant differences in the rate of surgical complications between lymphadenectomy versus no lymphadenectomy when performing radical nephrectomy. However, this finding was based on a single study which was not adequately powered to address this issue. There was no comparative study on which to make conclusions concerning concomitant adrenalectomy during radical or partial nephrectomy in relation to perioperative or QoL outcomes. Although the decision to undertake lymphadenectomy or ipsilateral adrenalectomy should be oncologically driven, comparative data on perioperative, QoL and adverse effect outcomes for these procedures are important because such data can be used to counsel patients appropriately and to facilitate service provision.

This review highlights several important gaps in knowledge in the evidence base. Only 7 of the 29 included studies were RCTs, which reflects the generally low quality of available evidence. Very few studies assessed QoL outcome measures. Patients with RCC are increasingly presenting at an earlier stage of their disease; indeed data from prospective studies show that the majority of tumours diagnosed are localised and $<7 \mathrm{~cm}$. Such small RCCs are generally associated with a good prognosis, such that the focus is now shifting to procedures that are not only minimally invasive but also focal in nature in order to preserve renal function. Central to the comparative assessment of such procedures is their impact on generic and disease-specific QoL measures. It is imperative that future studies of novel therapies on localised renal cancer include QoL outcomes. Outcomes such as operative complications or QoL data were extremely heterogeneous between studies such that it became impossible to compare or pool data for meta-analysis in this review. The lack of standardisation in outcome reporting is reflected also in the GRADE evidence profiles [10]. In addition, the review also reflected the generally poor quality of surgical research concerning the management of localised renal cancers. There needs to be a systematic and methodical approach towards studying complex surgical procedures, and initiatives such as IDEAL [49] provide a structured and accountable process by which surgical interventions are evaluated properly in prospective developmental studies, randomized trials and prospective databases and registries.

An updated literature search performed in January 2012 (covering the period of October 2010 to January 2012) returned 240 abstracts, of which 13 studies were relevant to our review. Of these, two were RCTs [50,51] and one was a prospective matched pair NRS [52]. Baik et al [50] compared laparoendoscopic single-site radical nephrectomy with conventional laparoscopic radical nephrectomy in an economic evaluation and found the two interventions comparable. Park et al [51] also compared laparoendoscopic single-site radical nephrectomy with conventional laparoscopic radical nephrectomy and reported surgical and QoL outcomes. They found that laparoendoscopic single-site radical nephrectomy has equivalent surgical outcomes but better QoL outcomes than laparoscopic radical nephrectomy. Kiriluk et al [52] compared laparoscopic RFA or cryoablation with laparoscopic partial nephrectomy and found that laparoscopic partial nephrectomy had higher blood loss and longer operative time than laparoscopic RFA and cryoablation, but transfusion rate, length of hospital stay and long- term renal function outcomes were similar. Of the other 10 studies identified from the updated scoping literature search, two were population-based registries or databases $[53,54]$ and eight were retrospective cohort 
studies [47,55-61]. The findings of these studies are briefly summarised in Table 3 . These studies and other potentially relevant studies will be formally included in the next systematic review report update.

\subsection{Strengths and limitations of the review and discussion of how review findings compare with other recent systematic reviews and technology assessments by guideline panels}

The major limitations of this systematic review on surgical outcomes have been outlined in detail elsewhere [10]. Briefly, the strength of this report is the systematic review methodology and comprehensive scope. Weaknesses include the methodological concessions and risks of bias therein, that needed to be made to provide the best available evidence. For instance, although meta-analyses are not a necessary or sufficient characteristic in systematic reviews, they often help in reducing uncertainty. However, meta-analysis was only possible in one comparison, due to data heterogeneity.

The discussion of this review in relation to the EAU and AUA guidelines, and other published systemic reviews is also covered comprehensively elsewhere $[9,10]$. Briefly, the main difference lies in the strict inclusion criteria and assessment of the quality of evidence.

\section{Conclusions}

In terms of perioperative and QoL outcomes, partial nephrectomy results in significantly better preservation of renal function over radical nephrectomy regardless of choice of approach or technique. For tumours where partial nephrectomy is not technically feasible (e.g. $>4 \mathrm{~cm}$ ), there is no evidence that alternative procedures or techniques are better than laparoscopic radical nephrectomy which is the standard of care for these localised tumours. For laparoscopic radical nephrectomy, the choice of approach (e.g. transperitoneal or retroperitoneal) does not appear to impact on outcome. With regard to technical modifications of laparoscopic nephrectomy, such as hand-assisted, robotic assisted or single-port techniques, all of them appear to have similar perioperative outcomes to standard laparoscopic radical nephrectomy. There is no good evidence to suggest that minimally invasive procedures such as cryotherapy or RFA have superior perioperative or QoL outcomes to nephrectomy; as such, decisions regarding such interventions should be based on oncological outcomes. Whilst the indication for adrenalectomy or lymphadenectomy is oncologically driven, its impact on perioperative and QoL outcomes remains unclear. Overall, there was a paucity of data regarding QoL outcomes, and when reported, both QoL and perioperative outcomes were inconsistently defined, measured or reported. These findings should be interpreted in conjunction with the oncological outcomes article [9]. The current evidence base has considerable limitations due to studies of low methodological quality marked by high risks of bias, and hence it is imperative that future studies address these knowledge gaps in a prospective, robust and methodical manner. 


\section{Take Home Message}

Localised renal cancers are best managed by nephron sparing surgery where technically feasible. However, the evidence base for perioperative and quality of life outcomes has significant limitations due to studies of low methodological quality marked by high risks of bias.

\section{Acknowledgements}

The UCAN systematic review team would like to thank the EAU Guidelines on Renal Cell Carcinoma panel, and Karin Plass from the EAU, for meeting with us to discuss the results from this systematic review (in Amsterdam, February 2011) and for their invaluable insights on how to strengthen the interpretation of the findings. We would also like to thank Barney Reeves from the Cochrane non-randomised studies group for sharing with us a draft version of a Cochrane tool for assessing risk of bias in non-randomised studies tool, on which we based our assessment. Molly Neuberger also deserves thanks for her methodological advice, particularly in using the GRADE tool.

Members of the EAU Renal Cancer Guideline Panel:

Ljungberg B. Merseburger, A. S. Patard, J. J. Hora, M. Kuczyk, M. A. Hanbury, D. C. Mulders, P. F. A. Sinescu, I. C.

Members of the UCAN Reference Group for Renal Cancer:

Michael Aitchison, Philipp Dahm

Funding:

UCAN Urological Cancer Charity (www.ucanhelp.org.uk)

MacMillan Cancer Support (www.macmillan.org.uk)

Reference List

[1] Guideline for Management of the Clinical Stage 1 Renal Mass. American Urological Association, 2009. Available from: http://www.auanet.org/resources.cfm?ID=442 [accessed May 2011].

[2] Delakas D, Karyotis I, Daskalopoulos G et al. Nephron-sparing surgery for localized renal cell carcinoma with a normal contralateral kidney: a European three-center experience. Urology 2002;60:998-1002.

[3] Kwan KG, Matsumoto ED, Ablin RJ, Gold P. Radiofrequency ablation and cryoablation of renal tumours. Curr Oncol 2007;14:34-38. 
[4] Lam JS, Shvarts O, Alemozaffarder $M$ et al. Nephron-sparing surgery as the new gold standard for $\mathrm{T} 1<=7 \mathrm{~cm}$ renal cell carcinoma: Results of a contemporary UCLA series. J Urol 2004;171(Suppl):469.

[5] Ljungberg B, Cowan NC, Hanbury DC et al. EAU guidelines on renal cell carcinoma: the 2010 update. Eur Urol 2010;58:398-406.

[6] Nguyen CT, Campbell SC, Novick AC. Choice of Operation for Clinically Localized Renal Tumor. Urol Clin North Am 2008;35:645-655.

[7] Uzzo RG, Novick AC. Nephron sparing surgery for renal tumors: indications, techniques and outcomes. J Urol 2001;166:6-18.

[8] Dahm P, Chapple CR, Konety BR et al. The future of clinical practice guidelines in urology. Eur Urol 2011;60:72-74.

[9] Maclennan S, Imamura M, Lapitan MC et al. Systematic review of oncological outcomes following surgical management of localised renal cancer [in press]. Eur Urol 2012;61:972-993.

[10] Imamura M, MacLennan S, Lapitan MC et al. Systematic review of the clinical effectiveness of surgical management for localised renal cell carcinoma. University of Aberdeen, Academic Urology Unit, 2011. Aberdeen, UK. Available from: http://www.uroweb.org/?id=217\&tyid=1\&oid=4.

[11] Higgins JPT, Green S. Cochrane Handbook for Systematic Reviews of Interventions version 5.0.2. The Cochrane Collaboration, 2011. Available from URL:

http://www.cochrane-handbook.org/ [accessed May 2011].

[12] Ware JEJr, Sherbourne CD. The MOS 36-item short-form health survey (SF-36). I. Conceptual framework and item selection. Med Care 1992;30:473-483.

[13] Reeves B, Shea B, Wells G. Classifying non-randomised studies (NRS) and the assessing the risk of bias for a systematic review. Workshop at 18th Cochrane Colloquium, Keystone, Colorado, 2010.

[14] Higgins JP, Thompson SG, Deeks JJ, Altman DG. Measuring inconsistency in metaanalyses. BMJ 2003;327:557-560.

[15] Peng B, Zheng J-H, Xu D-F, Ren J-Z. Retroperitoneal laparoscopic nephrectomy and open nephrectomy for radical treatment of renal cell carcinoma: A comparison of clinical outcomes. Academic Journal of Second Military Medical University 2006;27:1167-1169.

[16] Gratzke C, Seitz M, Bayrle F et al. Quality of life and perioperative outcomes after retroperitoneoscopic radical nephrectomy (RN), open $\mathrm{RN}$ and nephron-sparing surgery in patients with renal cell carcinoma. BJU Int 2009;104:470-475. 
[17] Hemal AK, Kumar A, Kumar R et al. Laparoscopic versus open radical nephrectomy for large renal tumors: a long-term prospective comparison. J Urol 2007;177:862866.

[18] Desai MM, Strzempkowski B, Matin SF et al. Prospective randomized comparison of transperitoneal versus retroperitoneal laparoscopic radical nephrectomy. J Urol 2005;173:38-41.

[19] Nambirajan T, Jeschke S, Al-Zahrani $\mathrm{H}$ et al. Prospective, randomized controlled study: transperitoneal laparoscopic versus retroperitoneoscopic radical nephrectomy. Urology 2004;64:919-924.

[20] Nadler RB, Loeb S, Clemens JQ et al. A prospective study of laparoscopic radical nephrectomy for T1 tumors--is transperitoneal, retroperitoneal or hand assisted the best approach? J Urol 2006;175:1230-1233.

[21] Gabr AH, Gdor Y, Strope SA, Roberts WW, Wolf JS, Jr. Approach and specimen handling do not influence oncological perioperative and long-term outcomes after laparoscopic radical nephrectomy. J Urol 2009;182:874-880.

[22] Hemal AK, Kumar A. A prospective comparison of laparoscopic and robotic radical nephrectomy for T1-2NOMO renal cell carcinoma. World J Urol 2009;27:89-94.

[23] Park Y, Lee S, Ku J et al. Laparoendoscopic Single-Site Radical Nephrectomy for Localized Renal Cell Carcinoma: Comparison with Conventional Laparoscopic Surgery. J Endourol 2009;23(Suppl):A194.

[24] Soga N, Kato M, Masui S et al. Comparison of radical nephrectomy techniques in one center: Minimal incision portless endoscopic surgery versus laparoscopic surgery. Int J Urol 2008;15:1018-1021.

[25] D'Armiento M, Damiano R, Feleppa B et al. Elective conservative surgery for renal carcinoma versus radical nephrectomy: a prospective study. Br J Urol 1997;79:15-19.

[26] Van Poppel H, Da Pozzo L, Albrecht W et al. A prospective randomized EORTC intergroup phase 3 study comparing the complications of elective nephron-sparing surgery and radical nephrectomy for low-stage renal cell carcinoma. Eur Urol 2007;51:1606-1615.

[27] Poulakis V, Witzsch U, de VR, Moeckel M, Becht E. Quality of life after surgery for localized renal cell carcinoma: comparison between radical nephrectomy and nephron-sparing surgery. Urology 2003;62:814-820.

[28] Butler BP, Novick AC, Miller DP, Campbell SA, Licht MR. Management of small unilateral renal cell carcinomas: radical versus nephron-sparing surgery. Urology 1995;45:34-40. 
[29] Lee JH, You CH, Min GE et al. Comparison of the surgical outcome and renal function between radical and nephron-sparing surgery for renal cell carcinomas. Korean J Urol 2007;48:671-676.

[30] Shekarriz B, Upadhyay J, Shekarriz H et al. Comparison of costs and complications of radical and partial nephrectomy for treatment of localized renal cell carcinoma. Urology 2002;59:211-215.

[31] Simmons MN, Chung BI, Gill IS. Perioperative efficacy of laparoscopic partial nephrectomy for tumors larger than 4 cm. Eur Urol 2009;55:199-208.

[32] Dash A, Vickers AJ, Schachter LR et al. Comparison of outcomes in elective partial vs radical nephrectomy for clear cell renal cell carcinoma of 4-7 cm. BJU Int 2006;97:939-945.

[33] Gill IS, Kavoussi LR, Lane BR et al. Comparison of 1,800 laparoscopic and open partial nephrectomies for single renal tumors. J Urol 2007;178:41-46.

[34] Lane BR, Gill IS. 7-year oncological outcomes after laparoscopic and open partial nephrectomy. J Urol 2010;183:473-479.

[35] Gong EM, Orvieto MA, Zorn KC et al. Comparison of laparoscopic and open partial nephrectomy in clinical T1a renal tumors. J Endourol 2008;22:953-957.

[36] Marszalek M, Meixl H, Polajnar M et al. Laparoscopic and Open Partial Nephrectomy: A Matched-Pair Comparison of 200 Patients. Eur Urol 2009;55:1171-1178.

[37] Aron M, Koenig P, Kaouk JH et al. Robotic and laparoscopic partial nephrectomy: a matched-pair comparison from a high-volume centre. BJU Int 2008;102:86-92.

[38] Wu SD, Viprakasit DP, Cashy J et al. Radiofrequency ablation-assisted robotic laparoscopic partial nephrectomy without renal hilar vessel clamping versus laparoscopic partial nephrectomy: a comparison of perioperative outcomes. J Endourol 2010;24:385-391.

[39] Desai MM, Aron M, Gill IS. Laparoscopic partial nephrectomy versus laparoscopic cryoablation for the small renal tumor. Urology 2005;66(Suppl):23-28.

[40] O'Malley RL, Berger AD, Kanofsky JA et al. A matched-cohort comparison of laparoscopic cryoablation and laparoscopic partial nephrectomy for treating renal masses. BJU Int 2007;99:395-398.

[41] Ko YH, Park HS, Moon dG et al. A matched-cohort comparison of laparoscopic renal cryoablation using ultra-thin cryoprobes with open partial nephrectomy for the treatment of small renal cell carcinoma. Cancer Res Treat 2008;40:184-189.

[42] Blom JHM, Van PH, Marechal JM et al. Radical Nephrectomy with and without Lymph-Node Dissection: Final Results of European Organization for Research and 
Treatment of Cancer (EORTC) Randomized Phase 3 Trial 30881. Eur Urol 2009;55:2834.

[43] Huang WC, Levey AS, Serio AM et al. Chronic kidney disease after nephrectomy in patients with renal cortical tumours: a retrospective cohort study. Lancet Oncol 2006;7:735-740.

[44] Novick AC, Derweesh I. Open partial nephrectomy for renal tumours: current status. BJU Int 2005;95(Suppl 2):35-40.

[45] Weight CJ, Larson BT, Fergany AF et al. Nephrectomy induced chronic renal insufficiency is associated with increased risk of cardiovascular death and death from any cause in patients with localized cT1b renal masses. J Urol 2010;183:1317-1323.

[46] Tan HJ, Norton EC, Ye Z et al. Long-term survival following partial vs radical nephrectomy among older patients with early-stage kidney cancer. JAMA 2012;307:1629-1635.

[47] Sun M, Abdollah F, Shariat SF et al. Propensity-score matched comparison of complications, blood transfusions, length of stay, and in-hospital mortality between open and laparoscopic partial nephrectomy: A national series. Eur J Surg Oncol 2012;38:80-87.

[48] Kang DC, Palmer DA, Zarei M et al. A systematic review of the quality of evidence of ablative therapy for small renal masses. J Urol 2012;187:44-47.

[49] McCulloch P, Altman DG, Campbell WB et al. No surgical innovation without evaluation: the IDEAL recommendations. Lancet 2009;374:1105-1112.

[50] Baik KD, Park YH, Kim KT, Lee SB, Kim HH. Comparative study on operative costs of laparoendoscopic single-site and conventional laparoscopic radical nephrectomy for localized renal cell carcinoma. J Endourol 2011;25:A22-A23.

[51] Park YH, Baik KD, Kim KT, Lee SB, Kim HH. Prospective randomized controlledtrial of laparoendoscopic single-site versus conventional laparoscopic radical nephrectomy for localized renal cell carcinoma. J Endourol 2011;25:A85-A86.

[52] Kiriluk KJ, Shikanov SA, Steinberg GD, Shalhav AL, Lifshitz DA. Laparoscopic partial nephrectomy versus laparoscopic ablative therapy: a comparison of surgical and functional outcomes in a matched control study. J Endourol 2011;25:1867-1872.

[53] Kates M, Badalato GM, Pitman M, McKiernan JM. Increased Risk of Overall and Cardiovascular Mortality After Radical Nephrectomy for Renal Cell Carcinoma $2 \mathrm{~cm}$ or Less. J Urol 2011;186:1247-1253.

[54] Tan HJ, Wolf JS, Jr., Ye Z, Wei JT, Miller DC. Population-Level Comparative Effectiveness of Laparoscopic Versus Open Radical Nephrectomy for Patients With Kidney Cancer. Cancer 2011;117:4184-4193. 
[55] Altunrende F, Autorino R, Hillyer S et al. Image Guided Percutaneous Probe Ablation for Renal Tumors in 65 Solitary Kidneys: Functional and Oncological Outcomes. J Urol 2011;186:35-41.

[56] Bouliere F, Crepel M, Bigot P et al. Nephron-sparing surgery is superior to radical nephrectomy in preserving renal function outcome in tumors larger than $4 \mathrm{~cm}$. Prog Urol 2011;21:842-850.

[57] Jeon SH, Kwon TG, Rha KH et al. Comparison of laparoscopic versus open radical nephrectomy for large renal tumors: a retrospective analysis of multi-center results. BJU Int 2011;107:817-821.

[58] Mir SA, Best SL, Donnally IIIC et al. Minimally invasive nephrectomy: The influence of laparoendoscopic single-site surgery on patient selection, outcomes, and morbidity. Urology 2011;77:631-634.

[59] Mitchell CR, Atwell TD, Weisbrod AJ et al. Renal Function Outcomes in Patients Treated With Partial Nephrectomy Versus Percutaneous Ablation for Renal Tumors in a Solitary Kidney. J Urol 2011;186:1786-1790.

[60] Takagi T, Kondo T, lizuka J et al. Postoperative renal function after partial nephrectomy for renal cell carcinoma in patients with pre-existing chronic kidney disease: A comparison with radical nephrectomy. Int J Urol 2011;18:472-476.

[61] White MA, Autorino R, Spana G et al. Robotic laparoendoscopic single-site radical nephrectomy: surgical technique and comparative outcomes. Eur Urol 2011;59:815822. 
Table 1: Baseline characteristics and perioperative and quality of life confounder adjustment scores

\begin{tabular}{|c|c|c|c|c|c|c|c|c|}
\hline $\begin{array}{l}\text { Study/ } \\
\text { confounder } \\
\text { score }\end{array}$ & Comparison & $\mathbf{N}$ & 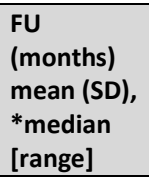 & $\begin{array}{l}\text { Age: } \\
\text { Mean } \\
\text { (SD), } \\
\text { *median } \\
\text { [range] }\end{array}$ & Sex Male & Ethnicity & $\begin{array}{l}\mathrm{N} \text { or Mean (SD) } \\
{ }^{*} \text { median } \\
\text { [range]Performance } \\
\text { score (ASA unless } \\
\text { otherwise stated) }\end{array}$ & Comorbidity \\
\hline \multirow[t]{2}{*}{$\begin{array}{l}\text { Peng } 2006 \\
\text { [15]; RCT }\end{array}$} & LRN & 27 & [6-12] & $\begin{array}{l}50.67 \\
(15.46)\end{array}$ & $\begin{array}{l}\text { M } 15 \\
\text { F } 12\end{array}$ & NR & NR & NR \\
\hline & ORN & 26 & {$[6-12]$} & $\begin{array}{l}52.53 \\
(15.12)\end{array}$ & $\begin{array}{l}\text { M } 15 \\
\text { F } 11\end{array}$ & NR & NR & NR \\
\hline \multirow{2}{*}{$\begin{array}{l}\text { Hemal } 2007 \\
\text { [17]; } \\
\text { prospective } \\
\text { cohort }\end{array}$} & LRN & 41 & $51.4[3,78]$ & $\begin{array}{l}52.5 \\
(11.3)\end{array}$ & $\begin{array}{l}\text { M } 24 \\
\text { F } 17\end{array}$ & NR & $1.95(0.95)$ & NR \\
\hline & ORN & 71 & $57.2[4,80]$ & $\begin{array}{l}52.7 \\
(11.8) \\
\end{array}$ & $\begin{array}{l}\text { M 47 } \\
\text { F } 24\end{array}$ & NR & $1.75(0.745)$ & NR \\
\hline Adjustment & ORN & NA & NA & 1 & NA & 5 & 1 & 5 \\
\hline \multirow{2}{*}{$\begin{array}{l}\text { Gratzke } 2009 \\
\text { [16]; database } \\
\text { review } \\
\text { (Ludwig- } \\
\text { Maximillian } \\
\text { and Basel } \\
\text { University) }\end{array}$} & LRN & 36 & 22 [11-71] & $\begin{array}{l}67.8 \\
(12.8)\end{array}$ & $\begin{array}{l}\text { M } 23 \\
F 13\end{array}$ & $\mathrm{NR}$ & $\begin{array}{l}\text { 1: } 0 \\
2: 20(56 \%) \\
3: 16(44 \%) \\
4: 0\end{array}$ & NR \\
\hline & ORN & 37 & $22[11-71]$ & $\begin{array}{l}61.1 \\
(12.7)\end{array}$ & $\begin{array}{l}\text { M } 23 \\
\text { F } 14\end{array}$ & NR & $\begin{array}{l}1: 3(8 \%) \\
2: 21(57 \%) \\
3: 13(35 \%) \\
4: 0 \\
\end{array}$ & NR \\
\hline Adjustment & NA & NA & NA & 5 & NA & 5 & 1 & 5 \\
\hline \multirow[t]{2}{*}{$\begin{array}{l}\text { Nambirajan } \\
2004 \text { [19]; RCT }\end{array}$} & RLRN & 20 & 15 [6-26] & $\begin{array}{l}66.8[43- \\
82]\end{array}$ & $\begin{array}{l}\text { M 9, } \\
\text { F } 11\end{array}$ & NR & 2.35 & NR \\
\hline & TLRN & 20 & $17[6-16]$ & $\begin{array}{l}62.2[41- \\
80]\end{array}$ & $\begin{array}{l}\text { M 12, } \\
\text { F } 8\end{array}$ & NR & 2.05 & NR \\
\hline \multirow{2}{*}{$\begin{array}{l}\text { Nadler } 2006 \\
\text { [20]; QRCT }\end{array}$} & RLRN & 11 & $* 20[0-51]$ & $61[42-85]$ & NR & NR & $2.2(0.4)$ & NR \\
\hline & TLRN & 11 & & $63[50-86]$ & NR & NR & $2.5[0.5]$ & NR \\
\hline \multirow[t]{2}{*}{$\begin{array}{l}\text { Desai 2005a } \\
\text { [18]; RCT }\end{array}$} & RLRN & 52 & $\begin{array}{l}13.5(11.9) \\
{[0.5-40]}\end{array}$ & $\begin{array}{l}64.5 \\
(12.3) \\
{[29-89]} \\
\end{array}$ & $\begin{array}{l}\text { M } 33 \\
\text { F } 19\end{array}$ & NR & $2.8(0.6)[1-4]$ & NR \\
\hline & TLRN & 50 & $\begin{array}{l}15(6.2)[3- \\
24]\end{array}$ & $\begin{array}{l}62.8 \\
(13.3)[30- \\
38] \\
\end{array}$ & M 26 & NR & $2.7(0.6)[2-4]$ & NR \\
\hline \multirow{2}{*}{$\begin{array}{l}\text { Nadler } 2006 \\
\text { [20]; QRCT }\end{array}$} & HALRN & 11 & $* 20[0-51]$ & 61 [42-85] & NR & NR & $2.2(0.4)$ & NR \\
\hline & TLRN & 11 & & $57[42-58]$ & NR & NR & 2.1. (0.8) & NR \\
\hline \multirow{2}{*}{$\begin{array}{l}\text { Gabr 2009b } \\
\text { [21]; database } \\
\text { review } \\
\text { (University of } \\
\text { Michigan } \\
\text { Health } \\
\text { System) } \\
\end{array}$} & HALRN & 108 & $\begin{array}{l}\text { Overall } \\
35.2(25) \\
{[0.3-114]} \\
* 30\end{array}$ & 61.3 (12.7 & $\begin{array}{l}\text { M 73 } \\
\text { F } 35\end{array}$ & NR & $\geq 3: 49$ & NR \\
\hline & TLRN & 147 & & $\begin{array}{l}62.7 \\
(12.9)\end{array}$ & $\begin{array}{l}\text { M } 81 \\
\text { F } 56\end{array}$ & NR & $\begin{array}{l}\geq 3: 52 \\
P=0.12\end{array}$ & NR \\
\hline Adjustment & NA & NA & NA & 1 & NA & 5 & 1 & 5 \\
\hline \multirow{2}{*}{$\begin{array}{l}\text { Nadler } 2006 \\
\text { [20]; QRCT }\end{array}$} & HALRN & 11 & $* 20[0-51]$ & 61 [42-85] & NR & NR & $2.2(0.4)$ & NR \\
\hline & RLRN & 11 & & $63[50-86]$ & NR & NR & $2.5[0.5]$ & NR \\
\hline \multirow{2}{*}{$\begin{array}{l}\text { Hemal } 2009 \\
\text { [22]; } \\
\text { prospective } \\
\text { cohort }\end{array}$} & Robot-RN & 15 & $8.3[1-12]$ & $\begin{array}{l}50.3 \\
(10.2)\end{array}$ & $\begin{array}{l}\text { M 8 } \\
\text { F }\end{array}$ & NR & NR & NR \\
\hline & LRN & 15 & $9.1[2-12]$ & $\begin{array}{l}52.7 \\
(11.8) \\
\end{array}$ & $\begin{array}{l}\mathrm{M} 6 \\
\mathrm{~F} 9\end{array}$ & NR & NR & NR \\
\hline Adjustment & & NA & NA & 1 & NA & 5 & 5 & 5 \\
\hline
\end{tabular}




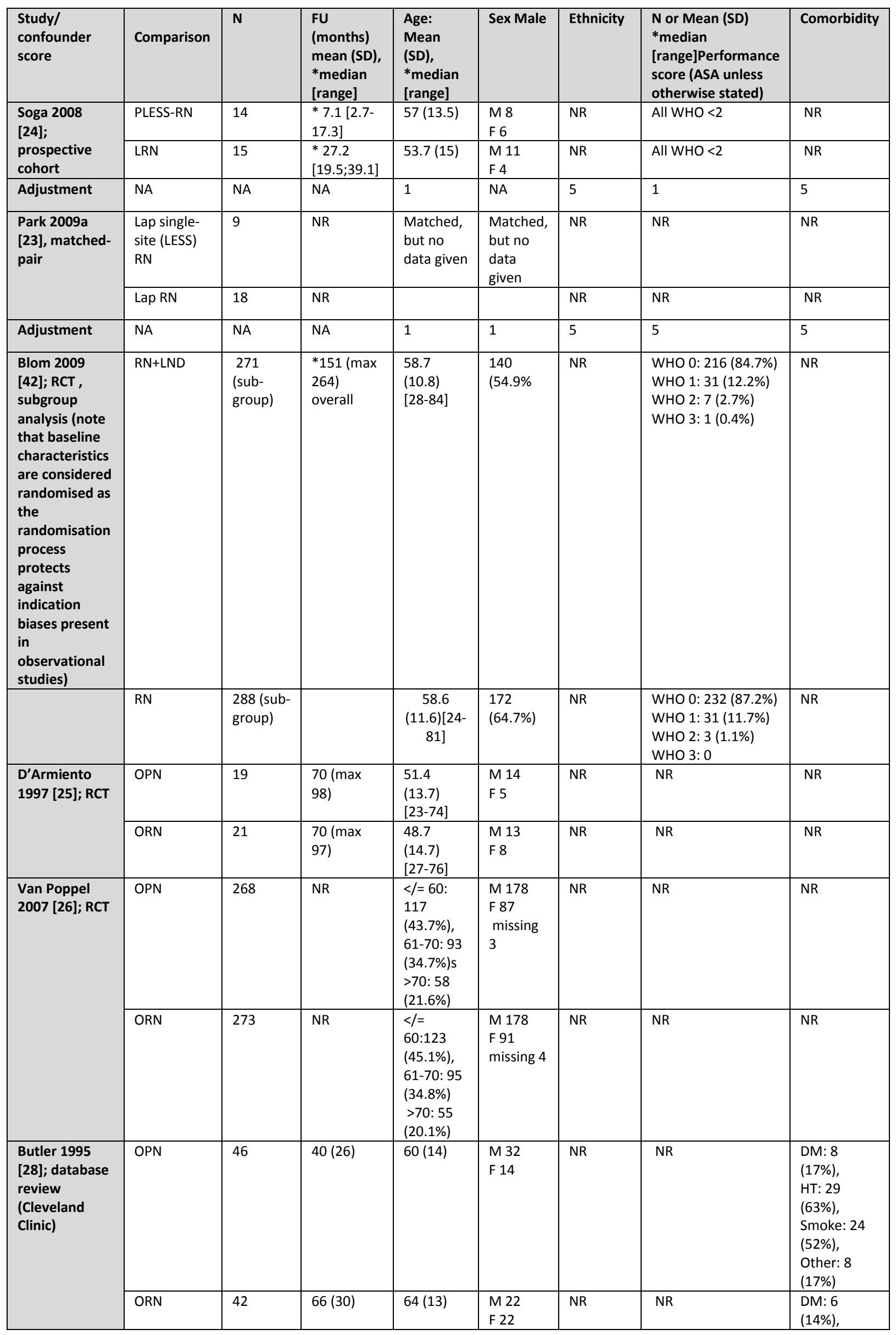




\begin{tabular}{|c|c|c|c|c|c|c|c|c|}
\hline $\begin{array}{l}\text { Study/ } \\
\text { confounder } \\
\text { score }\end{array}$ & Comparison & $\mathbf{N}$ & $\begin{array}{l}\text { FU } \\
\text { (months) } \\
\text { mean (SD), } \\
\text { *median }^{\text {med }} \\
\text { [range] } \\
\end{array}$ & $\begin{array}{l}\text { Age: } \\
\text { Mean } \\
\text { (SD), } \\
\text { *median } \\
\text { [range] } \\
\end{array}$ & Sex Male & Ethnicity & $\begin{array}{l}\mathrm{N} \text { or Mean (SD) } \\
\text { *median } \\
\text { [range]Performance } \\
\text { score (ASA unless } \\
\text { otherwise stated) } \\
\end{array}$ & Comorbidity \\
\hline & & & & & & & & $\begin{array}{l}\text { HT: } 20 \\
\text { (48\%), } \\
\text { Smoke: } 13 \\
\text { (31\%), } \\
\text { Other: } 6 \\
(14 \%)\end{array}$ \\
\hline Adjustment & NA & NA & NA & 1 & NA & 5 & 5 & 1 \\
\hline \multirow{2}{*}{$\begin{array}{l}\text { Gratzke } 2009 \\
\text { [16]; database } \\
\text { review } \\
\text { (Ludwig- } \\
\text { Maximillian } \\
\text { and Basel } \\
\text { University }\end{array}$} & OPN & 44 & $22[11-71]$ & $\begin{array}{l}60.7 \\
(12.4)\end{array}$ & $\begin{array}{l}\text { M } 29 \\
\text { F } 15\end{array}$ & $N R$ & $\begin{array}{l}1: 2(4 \%) \\
2: 30(67 \%) \\
3: 12(26 \%) \\
4: 1(2 \%) \\
\end{array}$ & NR \\
\hline & ORN & 37 & 22 [11-71] & $\begin{array}{l}61.1 \\
(12.7)\end{array}$ & $\begin{array}{l}\text { M } 23 \\
\text { F } 14\end{array}$ & $\mathrm{NR}$ & $\begin{array}{l}\text { 1: } 3(8 \%) \\
2: 21(57 \%) \\
3: 13(35 \%) \\
4: 0\end{array}$ & NR \\
\hline Adjustment & NA & NA & NA & 1 & NA & 5 & 1 & 5 \\
\hline \multirow[t]{2}{*}{$\begin{array}{l}\text { Lee } 2007 \text { [29]; } \\
\text { matched pair }\end{array}$} & OPN & 56 & $37.1(26.1)$ & $\begin{array}{l}51.8 \\
(11.7) \\
\end{array}$ & $\begin{array}{l}\text { M } 48 \\
\text { F } 8 \\
\end{array}$ & NA & NA & $\begin{array}{l}\text { HT: } 14 \\
\text { DM: } 13\end{array}$ \\
\hline & ORN & 56 & $39(20.37)$ & $\begin{array}{l}52.5 \\
(11.0) \\
\end{array}$ & $\begin{array}{l}\text { M } 42 \\
\text { F } 14\end{array}$ & NA & NA & $\begin{array}{l}\text { HT: } 21 \\
\text { DM: } 11\end{array}$ \\
\hline Adjustment & & NA & NA & NA & NA & NA & NA & NA \\
\hline \multirow[t]{2}{*}{$\begin{array}{l}\text { Poulakis } 2003 \\
\text { [27]; } \\
\text { prospective } \\
\text { cohort }\end{array}$} & OPN & $\begin{array}{l}29 \text { (sub- } \\
\text { group) }\end{array}$ & $\begin{array}{l}{ }^{*} 20[14- \\
27] \text { overall }\end{array}$ & $\begin{array}{l}\text { No } \\
\text { baseline } \\
\text { data for } \\
\text { subgroups }\end{array}$ & $\mathrm{NR}$ & NR & $N R$ & $\mathrm{NR}$ \\
\hline & ORN & $\begin{array}{l}22 \text { (sub- } \\
\text { group) }\end{array}$ & & $\begin{array}{l}\text { No } \\
\text { baseline } \\
\text { data for } \\
\text { subgroups }\end{array}$ & NR & NR & NR & $\mathrm{NR}$ \\
\hline Adjustment & NA & NA & NA & 5 & NA & 5 & 5 & 5 \\
\hline \multirow{2}{*}{$\begin{array}{l}\text { Shekkariz } 2002 \\
\text { [30]; matched } \\
\text { pair }\end{array}$} & OPN & 60 & NR & $62[40-76]$ & NR & NR & $N R$ & NR \\
\hline & ORN & 60 & NR & 65 [46-81] & NR & NR & NR & NR \\
\hline Adjustment & & NA & NA & 1 & NA & 5 & 5 & 5 \\
\hline \multirow{2}{*}{$\begin{array}{l}\text { Simmons } 2009 \\
\text { [31]; database } \\
\text { review }\end{array}$} & LPN & 35 & $\begin{array}{l}* 44(27- \\
85)\end{array}$ & $63.5(12)$ & $\begin{array}{l}\text { M } 26 \\
\text { F } 9\end{array}$ & & $2.7(0.5)$ & NR \\
\hline & LRN & 75 & ${ }^{*} 57(27-79)$ & $63.4(12)$ & $\begin{array}{l}\text { M } 39 \\
\text { F } 36\end{array}$ & & $2.6(0.6)$ & NR \\
\hline Adjustment & NA & NA & NA & 1 & NA & 5 & 1 & 5 \\
\hline \multirow[t]{2}{*}{$\begin{array}{l}\text { Dash } 2006 \\
\text { [32]; database } \\
\text { review (Sloan- } \\
\text { Kettering) }\end{array}$} & O/LPN & 45 & $* 21$ & $56.7(13)$ & $\begin{array}{l}\text { M } 32 \\
\text { F13 }\end{array}$ & NR & NR & $\begin{array}{l}\text { Vascular } \\
\text { invasion } \\
\text { absent: } 19 \\
\text { Present: } 1 \\
\text { Unknown: } \\
25 \\
\end{array}$ \\
\hline & ORN & 151 & $* 21$ & $\begin{array}{l}63.1 \\
(11.5)\end{array}$ & $\begin{array}{l}\text { M } 99 \\
\text { F } 52\end{array}$ & NR & NR & $\begin{array}{l}\text { Vascular } \\
\text { invasion } \\
\text { absent: } 97 \\
\text { Present: } 6 \\
\text { Unknown: } \\
48 \\
\end{array}$ \\
\hline Adjustment & NA & NA & NA & 1 & NA & 5 & 5 & 5 \\
\hline \multirow{2}{*}{$\begin{array}{l}\text { Gill } 2007 \text { [33]; } \\
\text { database } \\
\text { review } \\
\text { (Cleveland } \\
\text { Clinic, Mayo } \\
\text { Clinic and John } \\
\text { Hopkins } \\
\text { university) }\end{array}$} & LPN & 771 & $\begin{array}{l}* 14.4[0, \\
84]\end{array}$ & $\begin{array}{l}59.4[19- \\
87]\end{array}$ & $\begin{array}{l}\text { M } 442 \\
\text { F } 329\end{array}$ & $N R$ & $\begin{array}{l}\geq 3: 336 / 732(45.9 \%) \\
\text { ECOG } \geq 1: 11 / 771 \\
(1.4 \%)\end{array}$ & $\begin{array}{l}\text { Smoking } \\
\text { history: } 127 \\
\text { N of solitary } \\
\text { kidney: } 32 \\
\end{array}$ \\
\hline & OPN & 1029 & $\begin{array}{l}33.6[0, \\
91.2]\end{array}$ & $\begin{array}{l}61.6 \\
{[25.7-} \\
94.0]\end{array}$ & $\begin{array}{l}\text { M 724 } \\
\text { F } 305\end{array}$ & $N R$ & $\begin{array}{l}\geq 3: 398 / 525(75.8 \%) \\
\text { ECOG } \geq 1: 133 / 903\end{array}$ & $\begin{array}{l}\text { Smoking } \\
\text { history: } 417\end{array}$ \\
\hline
\end{tabular}




\begin{tabular}{|c|c|c|c|c|c|c|c|c|}
\hline $\begin{array}{l}\text { Study/ } \\
\text { confounder } \\
\text { score }\end{array}$ & Comparison & $\mathbf{N}$ & $\begin{array}{l}\text { FU } \\
\text { (months) } \\
\text { mean (SD), } \\
{ }^{*} \text { median } \\
\text { [range] }\end{array}$ & $\begin{array}{l}\text { Age: } \\
\text { Mean } \\
\text { (SD), } \\
{ }^{*} \text { median } \\
\text { [range] } \\
\end{array}$ & Sex Male & Ethnicity & $\begin{array}{l}\mathrm{N} \text { or Mean (SD) } \\
{ }^{*} \text { median } \\
\text { [range]Performance } \\
\text { score (ASA unless } \\
\text { otherwise stated) } \\
\end{array}$ & Comorbidity \\
\hline & & & & & & & $(14.7 \%)$ & $\begin{array}{l}\mathrm{N} \text { of solitary } \\
\text { kidney: } 222\end{array}$ \\
\hline Adjustment & NA & NA & NA & 1 & NA & 5 & 5 & 5 \\
\hline \multirow{2}{*}{$\begin{array}{l}\text { Gong } 2008 \\
\text { [35]; matched } \\
\text { pair }\end{array}$} & LPN & 76 & $21.7(25.6)$ & $\begin{array}{l}60.1 \\
(12.5)\end{array}$ & $\begin{array}{l}\text { M } 35 \\
\text { F 41 }\end{array}$ & NR & NR & NR \\
\hline & OPN & 77 & $20.6(23.1)$ & $\begin{array}{l}57.7 \\
(13.6)\end{array}$ & $\begin{array}{l}\text { M 42 } \\
\text { F 35 }\end{array}$ & NR & $N R$ & NR \\
\hline Adjustment & NA & NA & NA & 1 & NA & 5 & 5 & 5 \\
\hline \multirow[t]{2}{*}{$\begin{array}{l}\text { Lane } 2010 \\
\text { [34]; database } \\
\text { review } \\
\text { (Cleveland } \\
\text { clinic) }\end{array}$} & LPN & 672 & $\begin{array}{l}4 \text { yrs [IQR } \\
3.3-6.8]\end{array}$ & $\begin{array}{l}*^{*} 61 \text { [IQR } \\
51-69]\end{array}$ & $\begin{array}{l}\text { M } 395 \\
\text { F } 277\end{array}$ & $\begin{array}{l}\text { Caucasian } \\
613 \\
(92 \%) \\
\text { African- } \\
\text { American } \\
33(4.9 \%) \\
\text { Other } 26 \\
(3.9)\end{array}$ & *2 [IQR 2-3] & NR \\
\hline & OPN & 944 & $\begin{array}{l}* 5.7 \\
{[\text { IQR3.9- }} \\
7.3]\end{array}$ & $\begin{array}{l}* 61 \text { [IQR } \\
52-70]\end{array}$ & $\begin{array}{l}\text { M } 626 \\
\text { F } 318\end{array}$ & $\begin{array}{l}\text { Caucasian } \\
825 \\
(87 \%) \\
\text { African- } \\
\text { American } \\
65(6.8 \%) \\
\text { Other } 54 \\
(5.7 \%)\end{array}$ & *2 [IQR 2-3] & NR \\
\hline Adjustment & NA & NA & NA & 1 & NA & 1 & 1 & 5 \\
\hline \multirow[t]{2}{*}{$\begin{array}{l}\text { Marszalek } \\
2009[36] ; \\
\text { matched pair }\end{array}$} & LPN & 100 & $\begin{array}{l}44.4 \text { (SE: } \\
2.4)[19.2, \\
110.4] \\
\end{array}$ & $\begin{array}{l}62.3 \\
{[22.9-} \\
83.4] \\
\end{array}$ & $\begin{array}{l}\text { M } 60 \\
\text { F } 40\end{array}$ & NR & $N R$ & NR \\
\hline & OPN & 100 & $\begin{array}{l}42 \text { (SE: } 2.4) \\
{[12,117.6]}\end{array}$ & $\begin{array}{l}62.5 \\
{[21.9-} \\
84.6]\end{array}$ & $\begin{array}{l}\text { M 60 } \\
\text { F 40 }\end{array}$ & NR & NR & NR \\
\hline Adjustment & & NA & NA & 1 & $\mathrm{NA}$ & 5 & 5 & 5 \\
\hline \multirow{2}{*}{$\begin{array}{l}\text { Aron } 2008 \\
\text { [37]; matched } \\
\text { pair }\end{array}$} & Robot-LPN & 12 & 7.4 & $64(13.8)$ & $\begin{array}{l}\text { M } 8 \\
\text { F } 4\end{array}$ & NR & $2[1-3]$ & NR \\
\hline & LPN & 12 & 8.5 & $61(13.8)$ & $\begin{array}{l}\text { M } 8 \\
\text { F4 }\end{array}$ & NR & $2[1-3]$ & NR \\
\hline Adjustment & & NA & NA & 1 & NA & 5 & 1 & 5 \\
\hline \multirow[t]{2}{*}{$\begin{array}{l}\text { Desai 2005b } \\
\text { [39]; database } \\
\text { review }\end{array}$} & Lap-Cryo & $\begin{array}{l}78 \text { ( } 89 \\
\text { tumours) }\end{array}$ & $24.6[1-60]$ & $\begin{array}{l}65.55 \\
(12.69) \\
{[28-88]}\end{array}$ & $\begin{array}{l}\text { M } 54 \\
\text { F24 }\end{array}$ & NR & $\geq 3: 55$ & NR \\
\hline & LPN & $\begin{array}{l}153 \text { (153 } \\
\text { tumours) }\end{array}$ & $5.8[1-36]$ & $\begin{array}{l}60.59 \\
(13.19) \\
{[17-87]}\end{array}$ & $\begin{array}{l}\text { M } 89 \\
\text { F } 64\end{array}$ & NR & $\geq 3: 71$ & NR \\
\hline Adjustment & NA & & & 1 & & 5 & 5 & 5 \\
\hline \multirow{2}{*}{$\begin{array}{l}\text { O'Malley } 2007 \\
\text { [40]; matched } \\
\text { pair }\end{array}$} & Lap-Cryo & 15 & $11.9(7.2)$ & $76.1(4.5)$ & $\begin{array}{l}\mathrm{M} 9 \\
\mathrm{~F} 6\end{array}$ & & $\geq 3: 9$ & $\begin{array}{l}>1 \\
\text { comorbid: } 7\end{array}$ \\
\hline & LPN & 15 & $9.83(8.8)$ & $75.7(4.6)$ & $\begin{array}{l}\text { M } 12 \\
\text { F } 3\end{array}$ & & $\geq 3: 8$ & $\begin{array}{l}>1 \\
\text { comorbid: } 7\end{array}$ \\
\hline Adjustment & NA & NA & NA & 1 & NA & 5 & 1 & 1 \\
\hline \multirow[t]{2}{*}{$\begin{array}{l}\text { Ko } 2008 \text { [41]; } \\
\text { matched pair }\end{array}$} & Lap-Cryo & 20 & $27.3(10.8)$ & $\begin{array}{l}56.3 \\
(11.5) \\
{[24-76]}\end{array}$ & $\begin{array}{l}\text { M } 14 \\
\text { F } 6\end{array}$ & NR & $\begin{array}{l}1: 5 \\
2: 7 \\
3: 7 \\
4: 1\end{array}$ & NR \\
\hline & OPN & 20 & $28.7(14.9)$ & $\begin{array}{l}57.6 \\
(10.9) \\
{[44-77]}\end{array}$ & $\begin{array}{l}\text { M } 15 \\
\text { F } 5\end{array}$ & NR & $\begin{array}{l}1: 8 \\
2: 9 \\
3: 3 \\
4: 0\end{array}$ & NR \\
\hline Adjustment & NA & NA & NA & 1 & NA & 5 & 5 & 5 \\
\hline
\end{tabular}




\begin{tabular}{|c|c|c|c|c|c|c|c|c|}
\hline $\begin{array}{l}\text { Study/ } \\
\text { confounder } \\
\text { score }\end{array}$ & Comparison & $\mathbf{N}$ & $\begin{array}{l}\text { FU } \\
\text { (months) } \\
\text { mean (SD), } \\
\text { *median } \\
\text { [range] }\end{array}$ & $\begin{array}{l}\text { Age: } \\
\text { Mean } \\
\text { (SD), } \\
\text { *median } \\
\text { [range] }\end{array}$ & Sex Male & Ethnicity & $\begin{array}{l}\mathbf{N} \text { or Mean (SD) } \\
{ }^{*} \text { median } \\
\text { [range]Performance } \\
\text { score (ASA unless } \\
\text { otherwise stated) }\end{array}$ & Comorbidity \\
\hline \multirow{2}{*}{$\begin{array}{l}\text { Wu } 2010[38] \\
\text { database } \\
\text { review } \\
\text { (Northwestern } \\
\text { University of } \\
\text { Feinberg } \\
\text { medical } \\
\text { school) }\end{array}$} & RFRCPN & 42 & $\begin{array}{l}25.8[0.5, \\
71.5]\end{array}$ & $56[27-77]$ & $\begin{array}{l}\text { M } 24 \\
\text { F } 18\end{array}$ & NR & $\geq 3: 10 / 41(24.4 \%)$ & NR \\
\hline & LPN & 36 & $\begin{array}{l}7.8[1.0, \\
18.9]\end{array}$ & $58[36-79]$ & $\begin{array}{l}\text { M } 22 \\
\text { F } 14\end{array}$ & NR & $\geq 3: 11 / 34(30.6 \%)$ & NR \\
\hline Adjustment & NA & NA & NA & 2 & NA & 5 & 1 & 5 \\
\hline \multicolumn{9}{|c|}{$\begin{array}{l}\text { NA = not applicable; NR = not reported; SM = surgical management; NSM = non-surgical management; HALRN - hand-assisted } \\
\text { laparoscopic radical nephrectomy; SLRN = standard laparoscopic radical nephrectomy; RLRN = retroperitoneal laparoscopic radical } \\
\text { nephrectomy; TRLRN = transperitoneal laparoscopic radical nephrectomy; Robotic RN = robotic radical nephrectomy; LRN = laparoscopic } \\
\text { radical nephrectomy; PLRN = portless laparoscopic radical nephrectomy; RN = radical nephrectomy; RN+LND = radical nephrectomy + } \\
\text { lymph node dissection; OPN = open partial nephrectomy; ORN = Open radical nephrectomy; } \mathrm{LPN}=\text { laparoscopic partial nephrectomy; } \\
\mathrm{O} / \mathrm{LPN}=\text { open or laparoscopic partial nephrectomy; O/LRN = open or partial laparoscopic radical nephrectomy; RF-RCPN = radiofrequency } \\
\text { assisted robotic clampless partial nephrectomy; Lap-cryo = laparoscopic cryoablation; DM = Diabetes Mellitus; HT = Hypertension; Smoke } \\
=\text { smoker }\end{array}$} \\
\hline
\end{tabular}


Table 2: Renal function, postoperative complications and quality of life outcomes

\begin{tabular}{|c|c|c|c|c|c|c|c|c|c|}
\hline \multirow[t]{2}{*}{$\begin{array}{l}\text { Experimental } \\
\text { (Exp) }\end{array}$} & \multirow[t]{2}{*}{ Control (Ctr) } & \multirow[t]{2}{*}{ Author } & \multirow[t]{2}{*}{ Outcome } & \multicolumn{2}{|c|}{$\begin{array}{c}\mathrm{N} \text { at } \\
\text { baseline }\end{array}$} & \multicolumn{2}{|c|}{ Value } & \multirow[t]{2}{*}{ Reported P values } & \multirow[t]{2}{*}{ Note } \\
\hline & & & & Exp & Ctr & Exp & Ctr & & \\
\hline \multirow[t]{3}{*}{$\begin{array}{l}\text { Laparoscopic } \\
\text { radical } \\
\text { nephrectomy }\end{array}$} & \multirow[t]{3}{*}{$\begin{array}{l}\text { Open radical } \\
\text { nephrectomy }\end{array}$} & $\begin{array}{l}\text { Gratzke } \\
2009[16]\end{array}$ & $\begin{array}{l}\text { Post op renal } \\
\text { function }\end{array}$ & 36 & 37 & $34 \%$ & $18 \%$ & NR & $\begin{array}{l}\text { Measure by \% change in serum } \\
\text { creatinine } 6 \text { months after } \\
\text { baseline }\end{array}$ \\
\hline & & $\begin{array}{l}\text { Gratzke } \\
2009[16]\end{array}$ & $\begin{array}{l}\text { QoL-SF } 36 \text { mental } \\
\text { component }\end{array}$ & 36 & 37 & 48 & 48.3 & $\begin{array}{l}\mathrm{p} \text {-values (between } \\
\text { the three treatment } \\
\text { groups) were not } \\
\text { significant and were } \\
\text { within } 1 \mathrm{SD} \text { of the } \\
\text { age matched norm } \\
\end{array}$ & At mean Fu of 22 months \\
\hline & & $\begin{array}{l}\text { Gratzke } \\
2009[16]\end{array}$ & $\begin{array}{l}\text { QoL-SF } 36 \text { physical } \\
\text { component }\end{array}$ & 36 & 37 & 47.4 & 48 & $\begin{array}{l}\mathrm{p} \text {-values (between } \\
\text { the three treatment } \\
\text { groups) were not } \\
\text { significant and were } \\
\text { within } 1 \text { SD of the } \\
\text { age matched norm } \\
\end{array}$ & At mean Fu of 22 months \\
\hline \multirow{3}{*}{$\begin{array}{l}\text { Radical } \\
\text { nephrectomy with } \\
\text { limited or } \\
\text { extended lymph } \\
\text { node dissection }\end{array}$} & \multirow[t]{3}{*}{$\begin{array}{l}\text { Radical } \\
\text { nephrectomy }\end{array}$} & $\begin{array}{l}\text { Blom } 2009 \\
{[42]}\end{array}$ & $\begin{array}{l}\text { Postoperative } \\
\text { bleeding }>1 \mathrm{~L}\end{array}$ & 271 & 288 & $6.7 \%$ & $4.6 \%$ & n.s & \\
\hline & & $\begin{array}{l}\text { Blom } 2009 \\
{[42]} \\
\end{array}$ & Embolism & 271 & 288 & $2 \%$ & $0.4 \%$ & n.s & \\
\hline & & $\begin{array}{l}\text { Blom } 2009 \\
{[42]} \\
\end{array}$ & $\begin{array}{l}\text { Postoperative } \\
\text { infection }\end{array}$ & 271 & 288 & $5.1 \%$ & $5.8 \%$ & n.s & \\
\hline \multirow[t]{5}{*}{$\begin{array}{l}\text { Open partial } \\
\text { nephrectomy }\end{array}$} & \multirow[t]{5}{*}{$\begin{array}{l}\text { Open radical } \\
\text { nephrectomy }\end{array}$} & $\begin{array}{l}\text { Gratzke } \\
2009[16] \\
\end{array}$ & $\begin{array}{l}\text { Mean [range] } \\
\text { minutes WIT }\end{array}$ & 36 & 37 & $18[9,39]$ & NA & NA & \\
\hline & & $\begin{array}{l}\text { Gratzke } \\
2009[16]\end{array}$ & $\begin{array}{l}\text { QoL-SF } 36 \text { mental } \\
\text { component }\end{array}$ & 34 & 27 & 44.5 & 48.3 & $\begin{array}{l}\mathrm{p} \text {-values (between } \\
\text { the three treatment } \\
\text { groups) were not } \\
\text { significant and were } \\
\text { within } 1 \text { SD of the } \\
\text { age matched norm }\end{array}$ & \\
\hline & & $\begin{array}{l}\text { Gratzke } \\
2009[16]\end{array}$ & $\begin{array}{l}\text { QoL - SF } 36 \text { physical } \\
\text { component }\end{array}$ & 34 & 27 & 47.2 & 48 & $\begin{array}{l}\mathrm{p} \text {-values (between } \\
\text { the three treatment } \\
\text { groups) were not } \\
\text { significant and were } \\
\text { within } 1 \text { SD of the } \\
\text { age matched norm } \\
\end{array}$ & \\
\hline & & \begin{tabular}{|l|} 
Van \\
Poppel \\
$2007[26]$ \\
\end{tabular} & $\begin{array}{l}\text { Postoperative renal } \\
\text { function }\end{array}$ & 268 & 273 & $1.29 \mathrm{mg} / \mathrm{dl}$ & $1.50 \mathrm{mg} / \mathrm{dl}$ & $>0.0001$ & $\begin{array}{l}\text { Measured by median Creatinine } \\
\text { level }\end{array}$ \\
\hline & & Butler & Postoperative renal & 46 & 43 & preoperative: $1.3(0.4)$ & preoperative: $1.1(0.3)$ & & Measured as difference between \\
\hline
\end{tabular}




\begin{tabular}{|c|c|c|c|c|c|c|c|c|c|}
\hline \multirow[t]{2}{*}{$\begin{array}{l}\text { Experimental } \\
\text { (Exp) }\end{array}$} & \multirow[t]{2}{*}{ Control (Ctr) } & \multirow{2}{*}{$\begin{array}{l}\text { Author } \\
1995[28]\end{array}$} & \multirow{2}{*}{$\begin{array}{l}\text { Outcome } \\
\text { function }\end{array}$} & \multicolumn{2}{|c|}{$\begin{array}{c}\mathrm{N} \text { at } \\
\text { baseline }\end{array}$} & \multicolumn{2}{|c|}{ Value } & \multirow[t]{2}{*}{ Reported P values } & \multirow{2}{*}{$\begin{array}{l}\text { Note } \\
\text { preoperative and postoperative } \\
\text { mean (SD) serum creatinine level }\end{array}$} \\
\hline & & & & & & $\begin{array}{l}\mathrm{mg} / \mathrm{dL} \text { vs. postoperative: } \\
1.3(0.6) \mathrm{mg} / \mathrm{dL} \text {, } \\
\text { preoperative: } 115(35) \\
\mu \mathrm{mol} / \mathrm{L} \text { vs. postoperative: } \\
115(53) \mu \mathrm{mol} / \mathrm{L}(\mathrm{p}=\mathrm{n} . \mathrm{s})\end{array}$ & $\begin{array}{l}\text { mg/dL vs. postoperative: } \\
1.5(0.4) \mathrm{mg} / \mathrm{dL} \text {, } \\
\text { Preoperative: } 97(26) \\
\mu \mathrm{mol} / \mathrm{L} \text { vs. postoperative: } \\
133(35) \mu \mathrm{mol} / \mathrm{L}(\mathrm{p}= \\
<0.001) .\end{array}$ & & \\
\hline & & \begin{tabular}{|l} 
Lee 2007 \\
[29]
\end{tabular} & $\begin{array}{l}\text { Renal function - } \\
\text { narrative } \\
\text { description (data } \\
\text { not shown) }\end{array}$ & 56 & 56 & & & & $\begin{array}{l}\text { A significantly greater proportion } \\
\text { of patients in the radical } \\
\text { nephrectomy group had impaired } \\
\text { postoperative renal function } \\
\text { (defined as serum creatinine }> \\
1.6 \mathrm{mg} / \mathrm{dL} \text { ) after controlling for } \\
\text { diabetes, hypertension and age }\end{array}$ \\
\hline \multirow{3}{*}{$\begin{array}{l}\text { Laparoscopic } \\
\text { partial } \\
\text { nephrectomy }\end{array}$} & \multirow{3}{*}{$\begin{array}{l}\text { Laparoscopic } \\
\text { radical } \\
\text { nephrectomy }\end{array}$} & \begin{tabular}{|l|} 
Simmons \\
2009 [31] \\
\end{tabular} & $\begin{array}{l}\text { Estimated GFR } \\
\text { decrease }\end{array}$ & 35 & 75 & $13 \mathrm{ml} / \mathrm{min}$ & $24 \mathrm{ml} / \mathrm{min}$ & 0.03 & \\
\hline & & \begin{tabular}{|l|} 
Simmons \\
2009 [31] \\
\end{tabular} & $\begin{array}{l}2 \text { stage CKD } \\
\text { increase }\end{array}$ & 35 & 75 & $0 \%$ & $12 \%$ & $<0.001$ & \\
\hline & & \begin{tabular}{|l|} 
Simmons \\
$2009[31]$ \\
\end{tabular} & $\begin{array}{l}\text { Mean (SD) minutes } \\
\text { WIT }\end{array}$ & 35 & 75 & $37(11)$ & NA & NA & \\
\hline \multirow{2}{*}{$\begin{array}{l}\text { Open or } \\
\text { laparoscopic } \\
\text { partial } \\
\text { nephrectomy }\end{array}$} & \multirow{2}{*}{$\begin{array}{l}\text { Open or } \\
\text { Laparoscopic } \\
\text { radical } \\
\text { nephrectomy }\end{array}$} & $\begin{array}{l}\text { Dash } 2006 \\
\text { [32] }\end{array}$ & $\begin{array}{l}\text { Mean postoperative } \\
\text { creatinine }\end{array}$ & 45 & 151 & & & & $\begin{array}{l}\text { Mean difference at } 3 \text { months: } \\
0.23 \mathrm{mg} / \mathrm{dl} ; 95 \% \mathrm{Cl} 0.11-0.34, \mathrm{p}< \\
0.0001\end{array}$ \\
\hline & & \begin{tabular}{|l|} 
Dash 2006 \\
[32]
\end{tabular} & $\begin{array}{l}\text { Mean postoperative } \\
\text { creatinine }\end{array}$ & 45 & 151 & & & & $\begin{array}{l}\text { Mean difference at } 6-12 \text { months: } \\
0.21 \mathrm{mg} / \mathrm{dl}, 95 \% \mathrm{Cl} 0.09-0.34, \mathrm{p}< \\
0.0001\end{array}$ \\
\hline \multirow{7}{*}{$\begin{array}{l}\text { Laparoscopic } \\
\text { partial } \\
\text { nephrectomy }\end{array}$} & \multirow[t]{4}{*}{$\begin{array}{l}\text { Open partial } \\
\text { nephrectomy }\end{array}$} & \begin{tabular}{|l|} 
Marszalek \\
$2009[36]$ \\
\end{tabular} & $\begin{array}{l}\text { Decline in GFR } \\
\text { (immediate) } \\
\end{array}$ & 100 & 100 & $8.8 \%$ & $0.8 \%$ & $<0.001$ & \\
\hline & & \begin{tabular}{|l|} 
Marszalek \\
$2009[36]$ \\
\end{tabular} & $\begin{array}{l}\text { Decline in GFR (at } \\
3.6 \text { years mean FU) }\end{array}$ & 100 & 100 & $10.9 \%$ & $10.6 \%$ & 0.8 & \\
\hline & & \begin{tabular}{|l|} 
Gong 2008 \\
{$[35]$} \\
\end{tabular} & $\begin{array}{l}\text { Postoperative } \\
\text { change in creatinine }\end{array}$ & 76 & 77 & $0.03 \mathrm{mg} / \mathrm{dL}$ & $0.21 \mathrm{mg} / \mathrm{dL}$ & 0.27 & \\
\hline & & \begin{tabular}{|l|} 
Gill 2007 \\
[33]
\end{tabular} & $\begin{array}{l}\text { Lowest SCr in } 90 \\
\text { days }\end{array}$ & 771 & 1029 & $1.18 \mathrm{mg} / \mathrm{dL}$ & $1.42 \mathrm{mg} / \mathrm{dL}$ & n.s. & \\
\hline & & $\begin{array}{l}\text { Marszalek } \\
2009[36]\end{array}$ & $\begin{array}{l}\text { Median [IQR] } \\
\text { minutes ischaemia } \\
\text { time }\end{array}$ & 100 & 100 & $23[19,27]$ (WIT) & $31[24,45](\mathrm{CIT})$ & $<0.001$ & \\
\hline & & \begin{tabular}{|l|} 
Gong 2008 \\
{$[35]$} \\
\end{tabular} & $\begin{array}{l}\text { Mean (SD) minutes } \\
\text { ischaemia time }\end{array}$ & 76 & 77 & $32.8[10.6]$ (WIT) & $\begin{array}{l}20.5 \text { [6.5] (all CIT, apart } \\
\text { from } 1 \text { patient) }\end{array}$ & $<0.001$ & \\
\hline & & \begin{tabular}{|l|} 
Gill 2007 \\
[33]
\end{tabular} & $\begin{array}{l}\text { Mean [range] } \\
\text { minutes WIT }\end{array}$ & 648 & 461 & $30.7[4,68]$ & $20.1[4,52]$ & & $\begin{array}{l}\text { Multivariate adjusted relative risk } \\
(95 \% \mathrm{Cl}), \mathrm{LPN} \text { vs. OPN: } 1.69(1.62, \\
1.77) \mathrm{p}=<0.0001\end{array}$ \\
\hline $\begin{array}{l}\text { Robotic partial } \\
\text { nephrectomy }\end{array}$ & $\begin{array}{l}\text { Laparoscopic } \\
\text { partial }\end{array}$ & \begin{tabular}{|l|} 
Aron 2008 \\
{$[37]$}
\end{tabular} & $\begin{array}{l}\text { Mean GFR at } 3 \\
\text { month post }\end{array}$ & 12 & 12 & $75 \mathrm{mg} / \mathrm{dL}$ & $72 \mathrm{mg} / \mathrm{dL}$ & 0.71 & \\
\hline
\end{tabular}




\begin{tabular}{|c|c|c|c|c|c|c|c|c|c|}
\hline \multirow[t]{4}{*}{$\begin{array}{l}\text { Experimental } \\
\text { (Exp) }\end{array}$} & \multirow{4}{*}{$\begin{array}{l}\text { Control (Ctr) } \\
\text { nephrectomy }\end{array}$} & \multirow{3}{*}{$\begin{array}{l}\text { Author } \\
\text { Aron } 2008 \\
{[37]} \\
\end{array}$} & \multirow{2}{*}{\begin{tabular}{|l|} 
Outcome \\
operation
\end{tabular}} & \multicolumn{2}{|c|}{$\begin{array}{c}\mathrm{N} \text { at } \\
\text { baseline }\end{array}$} & \multicolumn{2}{|c|}{ Value } & \multirow[t]{2}{*}{ Reported P values } & \multirow[t]{2}{*}{ Note } \\
\hline & & & & & & & & & \\
\hline & & & $\begin{array}{l}\text { Mean (SD) minutes } \\
\text { WIT }\end{array}$ & 12 & 12 & $23(6.6)$ & $22(10.8)$ & 0.89 & \\
\hline & & $\begin{array}{l}\text { Aron } 2008 \\
{[37]}\end{array}$ & $\begin{array}{l}\text { Mean (SD) minutes } \\
\text { WIT in } 6 \text { patients in } \\
\text { each arm who had } \\
\text { early unclamping }\end{array}$ & 6 & 6 & $21(6.5)$ & $14(3.5)$ & 0.05 & \\
\hline \multirow[t]{4}{*}{$\begin{array}{l}\text { Laparoscopic } \\
\text { cryoablation }\end{array}$} & \multirow[t]{4}{*}{$\begin{array}{l}\text { Laparoscopic } \\
\text { partial } \\
\text { nephrectomy }\end{array}$} & $\begin{array}{l}\text { Desai } \\
\text { 2005b [39] }\end{array}$ & $\begin{array}{l}\text { Mean rise in Serum } \\
\text { creatinine from } \\
\text { baseline }\end{array}$ & 78 & 153 & $16.4(21) \%$ & $13.7(37.9) \%$ & 0.081 & $\begin{array}{l}\text { \% Rise in serum creatinine }= \\
\text { Serum creatinine at } 1 \text { month } \\
\text { minus Baseline serum creatinine } \\
\text { divided by Baseline serum } \\
\text { creatinine multiplied by } 100 .\end{array}$ \\
\hline & & $\begin{array}{l}\text { O'Malley } \\
2007[40] \\
\end{array}$ & $\begin{array}{l}\text { Mean postoperative } \\
\text { creatinine }\end{array}$ & 15 & 15 & $1.18(0.24) \mathrm{mg} / \mathrm{dL}$ & $1.19(0.29) \mathrm{mg} / \mathrm{dL}$ & 0.89 & \\
\hline & & $\begin{array}{l}\text { Desai } \\
\text { 2005b [39] }\end{array}$ & $\begin{array}{l}\text { Mean (SD) minutes } \\
\text { WIT }\end{array}$ & 78 & 153 & NA & $30.2(8.5)$ & NA & \\
\hline & & $\begin{array}{l}\text { O'Malley } \\
2007[40] \\
\end{array}$ & $\begin{array}{l}\text { Mean (SD) minutes } \\
\text { WIT }\end{array}$ & 15 & 15 & NA & $27.6(6)$ & NA & \\
\hline \multirow[t]{2}{*}{ RFRCPN } & \multirow[t]{2}{*}{$\begin{array}{l}\text { Laparoscopic } \\
\text { partial } \\
\text { nephrectomy }\end{array}$} & $\begin{array}{l}\text { Wu } 2010 \\
{[38]}\end{array}$ & $\begin{array}{l}\text { Mean change in } \\
\text { serum creatinine } \\
\text { from baseline to last } \\
\text { axial radiological } \\
\text { imaging }\end{array}$ & 41 & 36 & $0.16 \mathrm{mg} / \mathrm{dL}$ & $0.13 \mathrm{mg} / \mathrm{dL}$ & 0.58 & \\
\hline & & $\begin{array}{l}\text { Wu } 2010 \\
\text { [38] }\end{array}$ & $\begin{array}{l}\text { Mean [range] } \\
\text { minutes WIT }\end{array}$ & 42 & 36 & NA & $31.1[0,52]$ & NA & \\
\hline
\end{tabular}

WIT = warm ischaemia time; $C I T$ = cold ischaemia time; $\mathrm{LPN}=$ laparoscopic partial nephrectomy; OPN = open partial nephrectomy; $N A=$ not applicable; $n . s=$ not significant 
Table 3: Brief summary of findings from studies identified in an updated scoping search (October 2010-January 2012)

\begin{tabular}{|c|c|c|c|c|}
\hline Study & Study design & Experimental & Control & Brief summary of findings \\
\hline Sun 2012 [47] & Retrospective cohort & OPN & LPN & Perioperative outcomes only: LPN has fewer adverse outcomes than OPN. \\
\hline $\begin{array}{l}\text { Altunrende } \\
2011[55]\end{array}$ & $\begin{array}{l}\text { Retrospective cohort (in } \\
\text { patients with a solitary kidney) }\end{array}$ & Cryotherapy & RFA & Oncological and functional outcomes: No evidence of a difference \\
\hline Baik 2011 [50] & RCT & LESS & LRN & Economic evaluation: LESS comparable with LRN in economic terms. \\
\hline $\begin{array}{ll}\text { Bouliere } 2011 \\
56]\end{array}$ & $\begin{array}{l}\text { Retrospective cohort (tumours } \\
<4 \mathrm{~cm} \text { only) }\end{array}$ & PN & $\mathrm{RN}$ & Renal function outcome only: PN better than RN. \\
\hline $\begin{array}{l}\text { Jeon } 2011 \\
{[57]}\end{array}$ & $\begin{array}{l}\text { Retrospective cohort } \\
\text { (Tumours }>7 \mathrm{~cm} \text { only) }\end{array}$ & LRN & ORN & Oncological and surgical outcomes: No evidence of a difference but LRN less invasive than ORN. \\
\hline $\begin{array}{l}\text { Kates } 2011 \\
{[53]}\end{array}$ & $\begin{array}{l}\text { Population-based } \\
\text { registry(tumours }<2 \mathrm{~cm} \text { only) }\end{array}$ & PN & RN & Overall and cardiovascular mortality: PN better for both outcomes. \\
\hline $\begin{array}{l}\text { Kiriluk } 2011 \\
{[52]}\end{array}$ & $\begin{array}{l}\text { Prospective matched-control } \\
\text { study }\end{array}$ & LRFA & LPN & $\begin{array}{l}\text { Perioperative and renal functional outcomes: LPN had higher blood loss and longer operative time; but transfusion rate, length of } \\
\text { hospital stay and long term renal function outcome similar. }\end{array}$ \\
\hline Mir 2011 [58] & Retrospective cohort & LESS & LRN & Perioperative outcomes only: No evidence of a difference \\
\hline $\begin{array}{l}\text { Mitchell } 2011 \\
\text { [59] }\end{array}$ & $\begin{array}{l}\text { Retrospective cohort (in } \\
\text { patients with a solitary kidney) }\end{array}$ & PA & PN & Renal function outcome only: No evidence of a difference \\
\hline Park 2011 [51] & RCT & LESS & LRN & Perioperative and QoL outcomes: No evidence of a difference in perioperative outcomes but LESS had better QoL outcomes than LRN. \\
\hline $\begin{array}{l}\text { Takagi } 2011 \\
{[60]}\end{array}$ & $\begin{array}{l}\text { Retrospective cohort (in } \\
\text { patients with chronic kidney } \\
\text { disease) }\end{array}$ & PN & RN & $\begin{array}{l}\text { Overall survival and renal function outcome only: PN could significantly prevent development to late-stage CKD in patients with } \\
\text { preoperative e-GFR } 45-59 \mathrm{~mL} / \mathrm{min} / 1.73 \mathrm{~m} 2 \text { compared with RN. However, there was no evidence of a difference between groups in } \\
\text { overall survival and the number of the patients who went on to develop end-stage renal disease requiring renal replacement therapy. }\end{array}$ \\
\hline Tan 2011 [54] & $\begin{array}{l}\text { Population-based registry } \\
\text { (SEER database) }\end{array}$ & LRN & ORN & Perioperative outcomes only: LRN had lower ICU admission and prolonged length of stay, but higher in-hospital mortality. \\
\hline $\begin{array}{l}\text { White } 2011 \\
\text { [61] }\end{array}$ & Retrospective cohort & Robotic LESS & LRN & Perioperative outcomes only: No evidence of a difference \\
\hline
\end{tabular}


Figure 1: PRISMA Flow Diagram

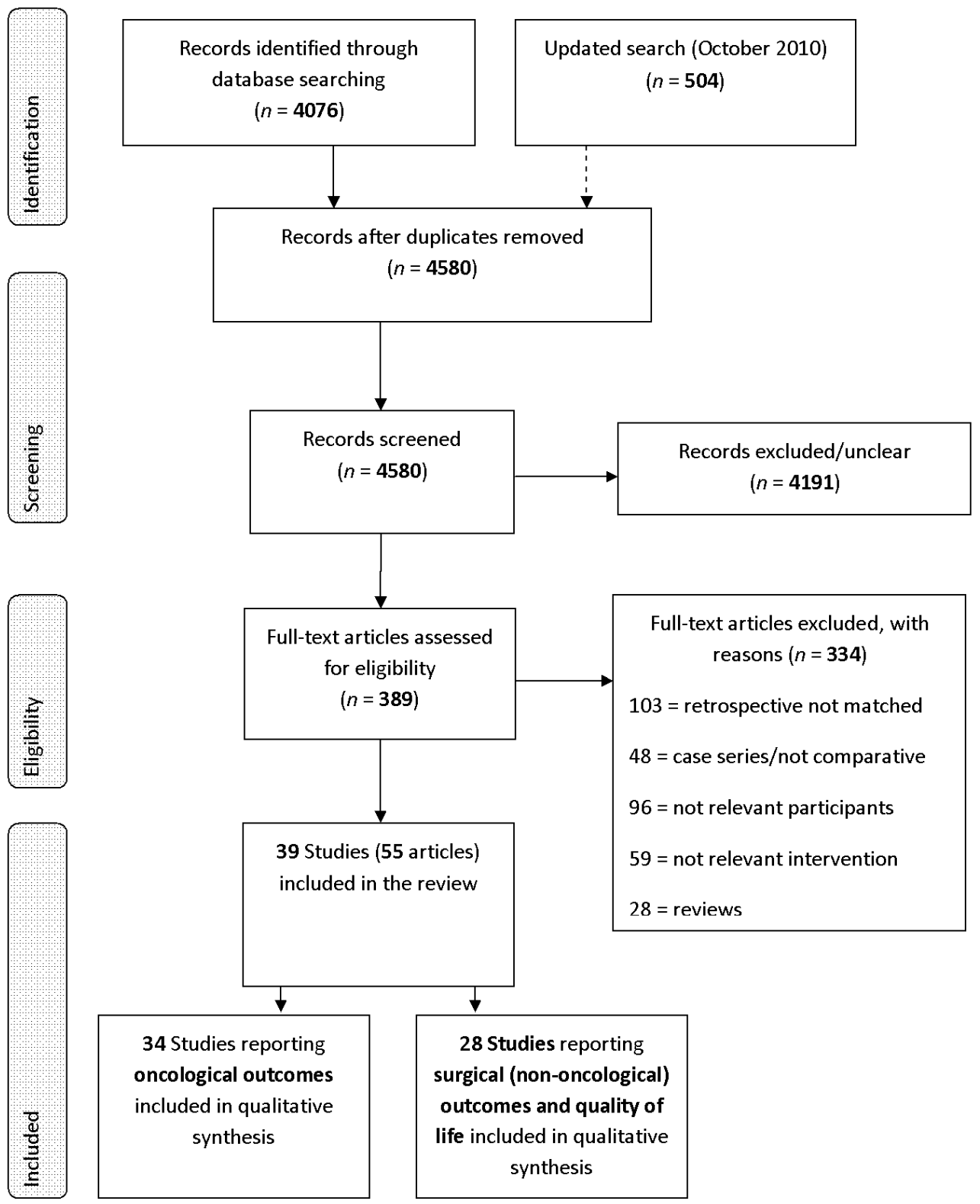


Figure 2: Length of hospital stay (days, mean, SD)

\begin{tabular}{|c|c|c|c|c|c|c|c|}
\hline \multirow[b]{2}{*}{ Study or Subgroup } & \multicolumn{3}{|c|}{ Experimental } & \multicolumn{3}{|c|}{ Control } & \multirow{2}{*}{$\begin{array}{l}\text { Mean Difference } \\
\text { IV, Fixed, } 95 \% \mathrm{Cl}\end{array}$} \\
\hline & Mean & SD & Total & Mean & SD & Total & \\
\hline \multicolumn{8}{|c|}{ 1.1.1 Laparoscopic radical (exp) vs. open radical (ctr) nephrectomy } \\
\hline Gratzke et al [16] & 7.2 & 2.9 & 36 & 9.1 & 3.5 & 37 & $-1.90[-3.37,-0.43]$ \\
\hline Hemal et al [17] & 3.6 & 0.79 & 41 & 6.6 & 1.06 & 71 & $3.35,-2.65]$ \\
\hline Peng et al [15] (RCT) & 6.92 & 0.96 & 27 & 11.42 & 1.57 & 26 & $-4.50[-5.20,-3.80]$ \\
\hline \multicolumn{8}{|c|}{ 1.1.2 Retroperitoneal (exp) vs. transperitoneal (ctr) laparascopic radical nephrectomy } \\
\hline Desai et al [18] (RCT) & 1.87 & 1.28 & 52 & 1.81 & 1.43 & 50 & $0.06[-0.47,0.59]$ \\
\hline Nadler et al [20] (Q-RCT) & 3.6 & 1.9 & 11 & 2.1 & 0.7 & 11 & $1.50[0.30,2.70]$ \\
\hline Nambirajan et al[19](RCT) & 7.6 & 4.7 & 20 & 7.2 & 2.7 & 20 & $0.40[-1.98,2.78]$ \\
\hline
\end{tabular}

1.1.3 Hand-assisted (exp) vs. transperitoneal (ctr) laparospic radical nephrectomy $\begin{array}{llllllll}\text { Nadler et al }[20](\mathrm{Q}-\mathrm{RCT}) & 3.4 & 1.7 & 11 & 2.1 & 0.7 & 11 & 1.30 \\ {[0.21,2.39]}\end{array}$

1.1.4 Hand-assisted (exp) vs. retroperitoneal (ctr) laparoscopic radical nephrectomy

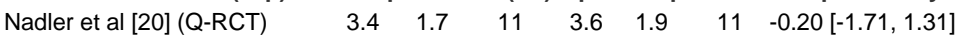

1.1.5 Hand-assisted (exp) vs. trans- or retro-peritoneal (ctr) laparoscopic radical nephrectomy $\begin{array}{llllllll}\text { Gabr et al [21] } & 2.8 & 1.6 & 108 & 2.4 & 1.7 & 147 & 0.40\end{array}\left[\begin{array}{l}-0.01,0.81\end{array}\right]$

1.1.6 Robotic (exp) vs. laparoscopic (ctr) radical nephrectomy

$\begin{array}{llllllll}\text { Hemal et al [22] } & 3.5 & 0.1 & 15 & 3.4 & 0.2 & 15 & 0.10\end{array}\left[\begin{array}{ll}-0.01,0.21\end{array}\right]$

1.1.7 Portless endoscopic (exp) vs. laparoscopic (ctr) radical nephrectomy

$\begin{array}{llllllll}\text { Park et al [23] } & 2.7 & 0 & 9 & 3.9 & 0 & 18 & \text { Not estimable }\end{array}$

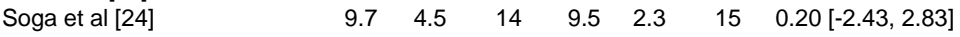

1.1.8 Open partial (exp) vs. open radical (ctr) nephrectomy

$\begin{array}{llllllll}\text { Buttler et al [28] } & 9.2 & 6.1 & 46 & 8.5 & 3.4 & 42 & 0.70[-1.34,2.74] \\ \text { Gratzke et al [16] } & 9.6 & 3.1 & 44 & 9.1 & 3.5 & 37 & 0.50[-0.95,1.95]\end{array}$

$\begin{array}{lrrrrrrr}\text { Gratzke et al [16] } & 9.6 & 3.1 & 44 & 9.1 & 3.5 & 37 & 0.50[-0.95,1.95] \\ \text { Shekarriz et al [30] } & 6.4 & 3 & 60 & 6.4 & 3.3 & 60 & 0.00[-1.13,1.13]\end{array}$

1.1.9 Laparoscopic partial (exp) vs. open partial (ctr) nephrectomy

$\begin{array}{llllllll}\text { Gill et al [33] } & 3.3 & 0 & 771 & 5.8 & 0 & 1029 & \text { Not estimable }\end{array}$

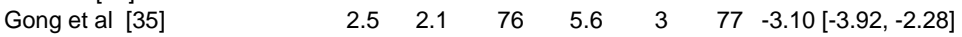

1.1.10 Robotic (exp) vs. laparoscopic (ctr) partial nephrectomy

$\begin{array}{llllllll}\text { Aron et al [37] } & 4.7 & 2.4 & 12 & 4.4 & 1.1 & 12 & 0.30 \\ {[-1.1 .19,1.79]}\end{array}$

1.1.11 Laparoscopic cryoablation (exp) vs. laparoscopic partial nephrectomy (ctr)

$\begin{array}{llllllll}\text { Desai et al [39] } & 2.1 & 2.9 & 78 & 2.3 & 2.8 & 153 & -0.20[-0.98,0.58]\end{array}$

$\begin{array}{llllllll}\text { O'Malley et al [40] } & 3.3 & 3.3 & 15 & 4.4 & 3.9 & 15 & -1.10\end{array}\left[\begin{array}{llll}-3.69,1.49\end{array}\right]$

1.1.12 Laparoscopic cryoablation (exp) vs. open partial nephrectomy (ctr)

$\begin{array}{llllllll}\text { Ko et al [41] } & 4.21 & 1.5 & 20 & 8.2 & 2.4 & 20 & -3.99 \\ {[-5.23,-2.75]}\end{array}$

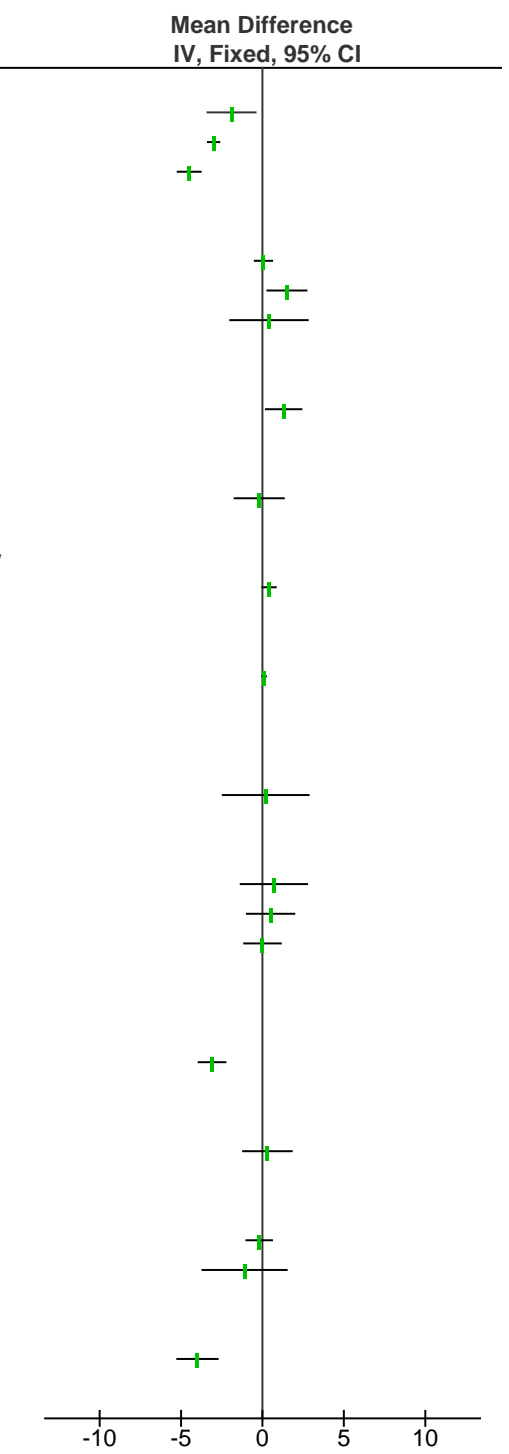

Favours experimental Favours control 


\section{Figure 3: Blood transfusion (number of patients).}

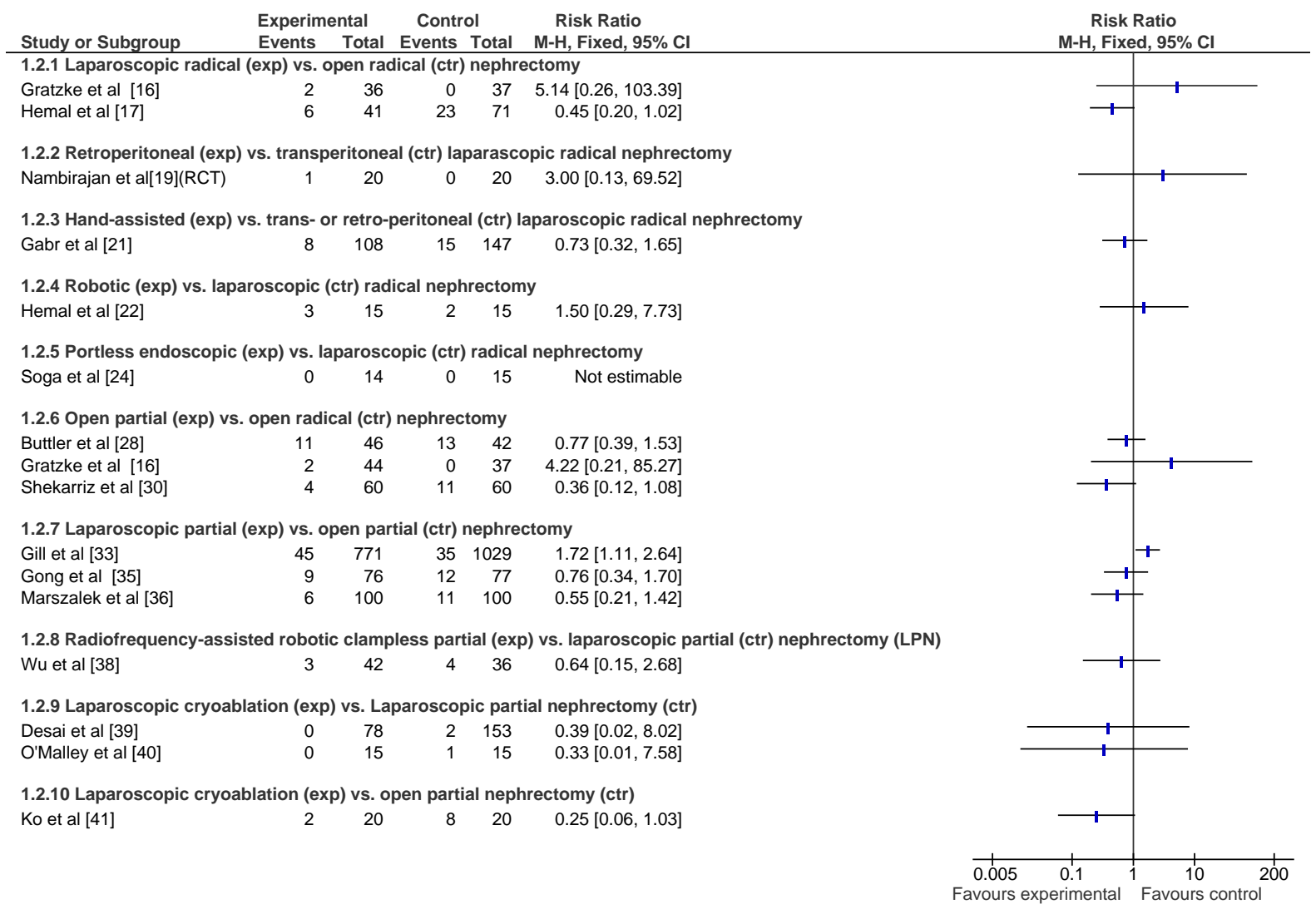

Figure 4: Analgesic requirement (mg morphine equivalent, mean, SD).

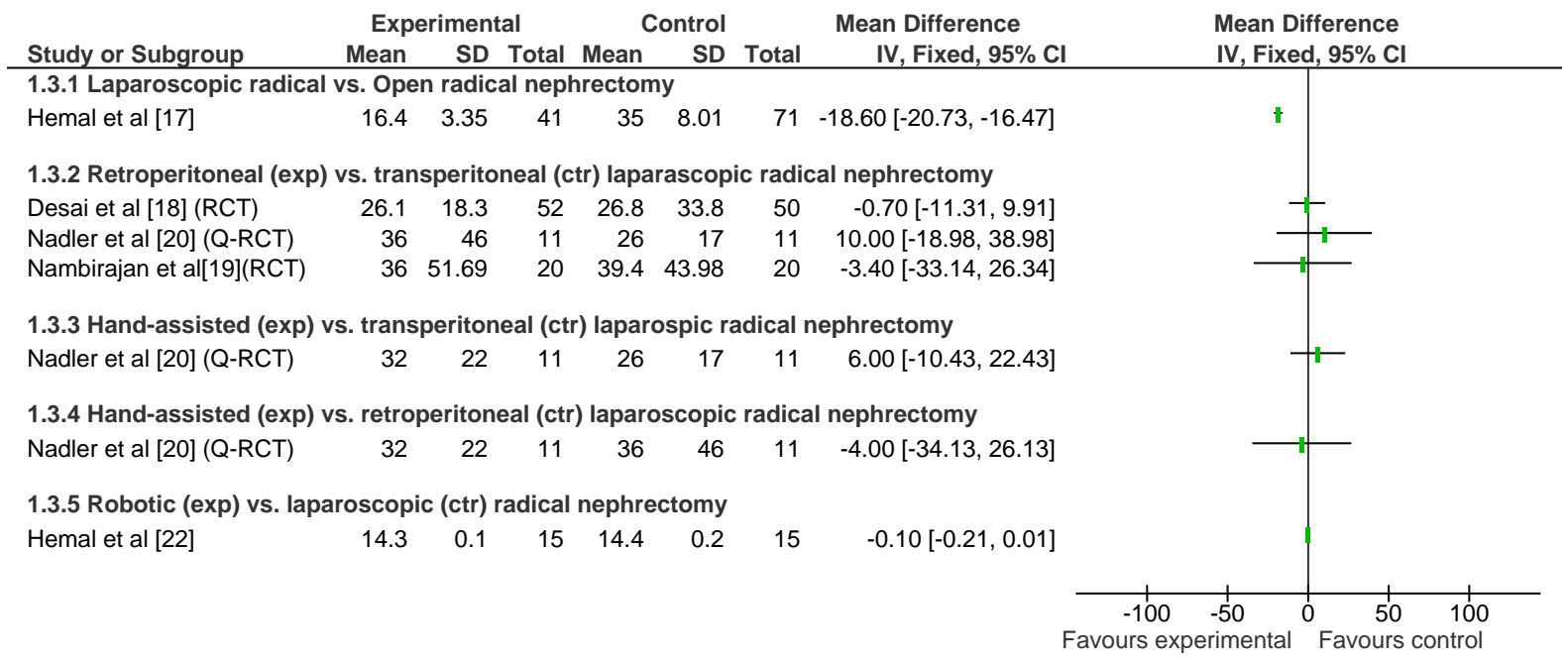


Figure 5: Convalescence time (weeks, mean, SD)

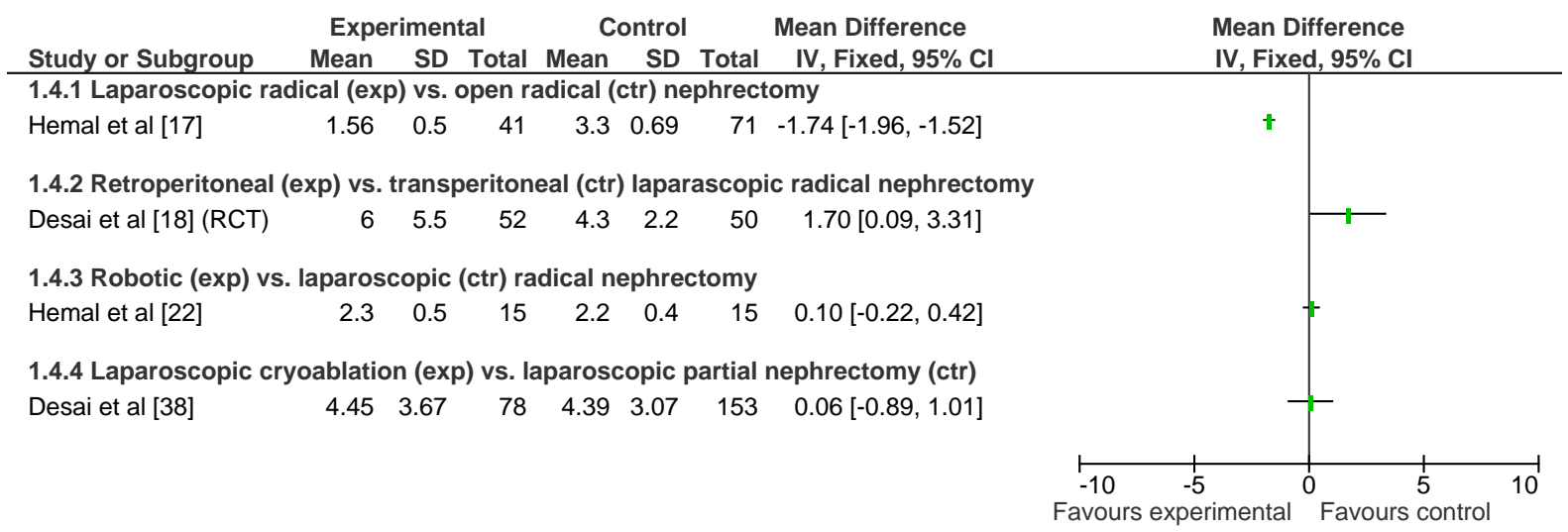

Figure 6: Blood loss (ml, mean, SD).

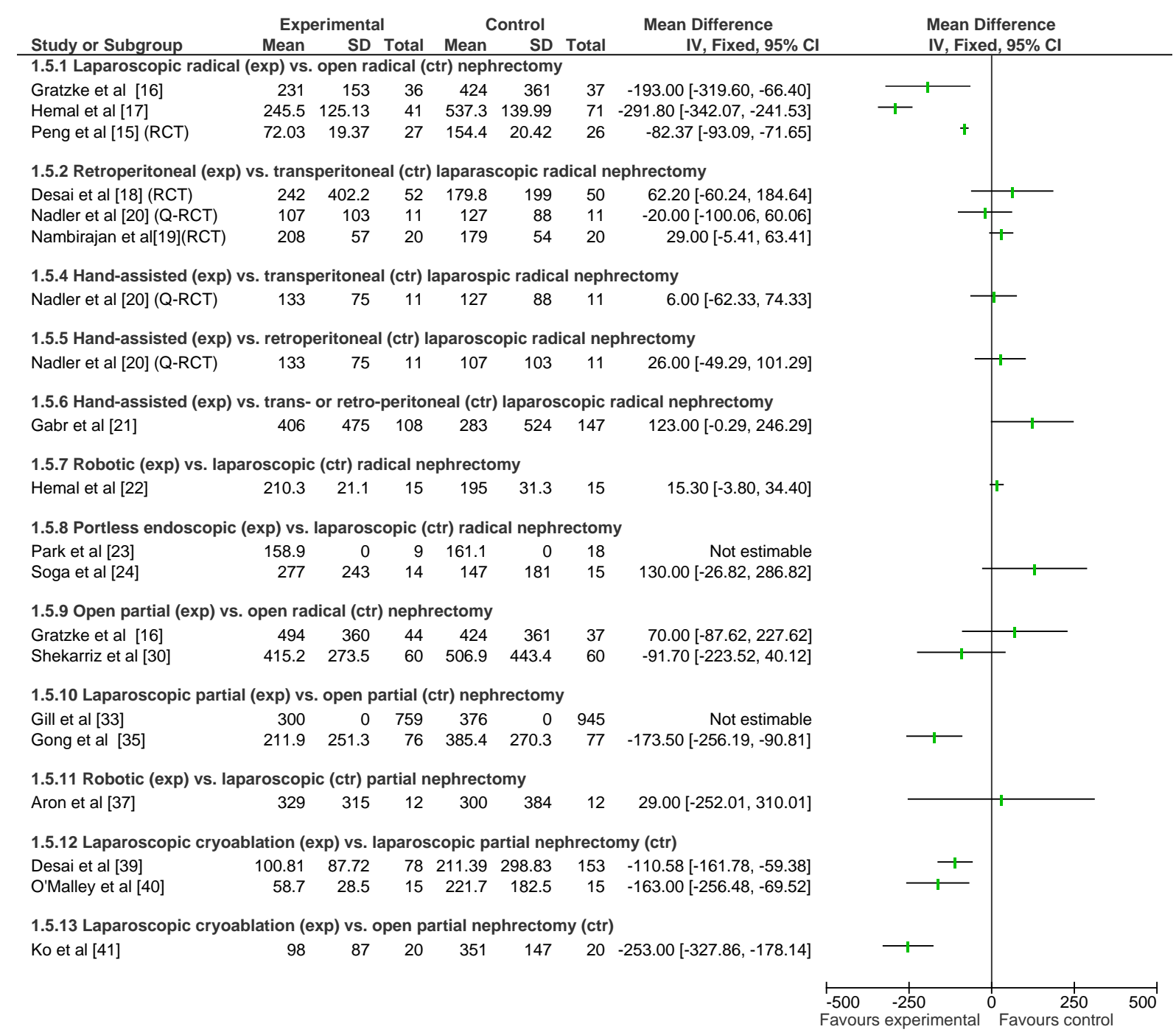


Figure 7: Duration of operation (minute, mean, SD).

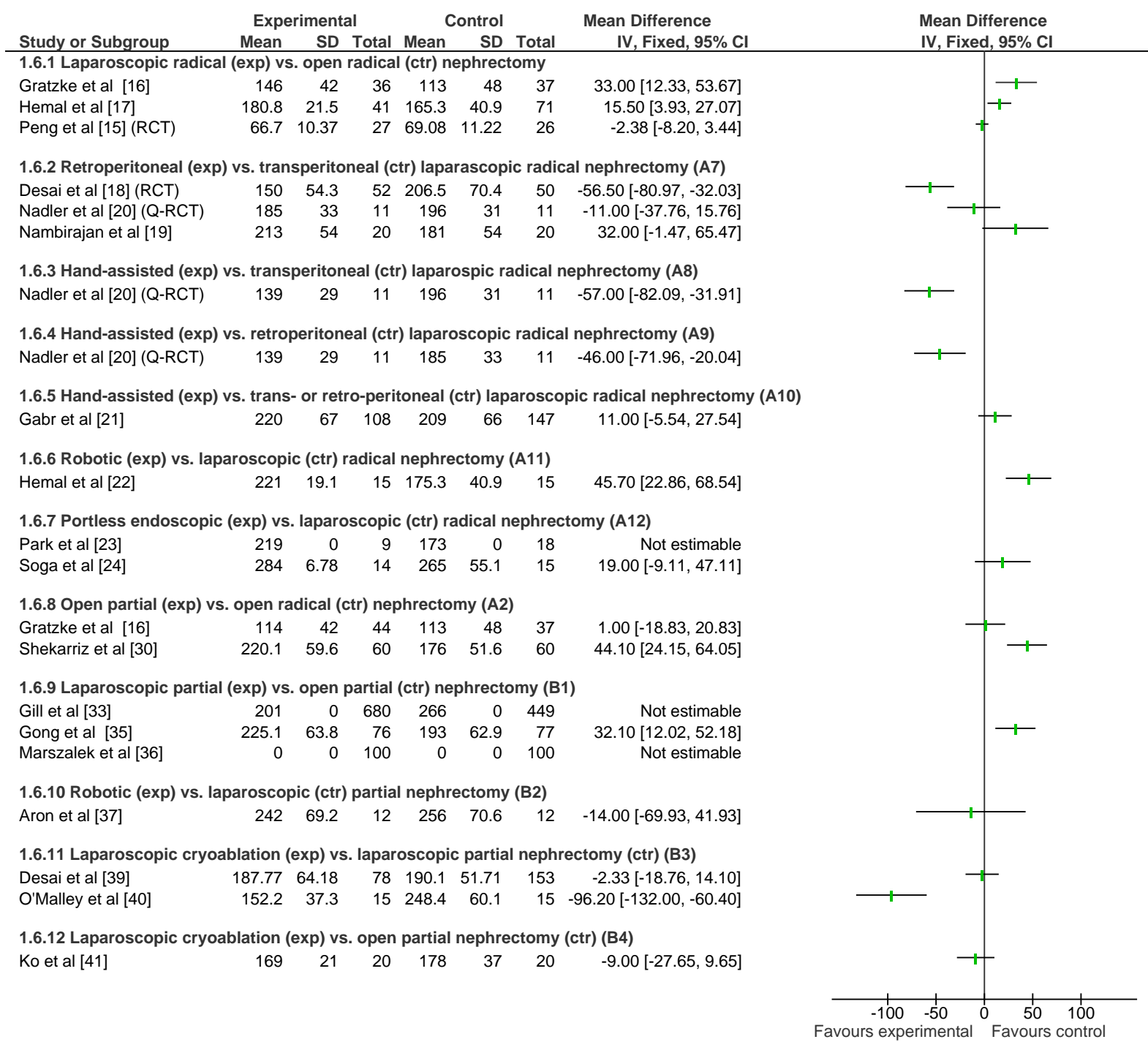

\section{Figure 8: Return to work at 2 weeks (number of patients).}

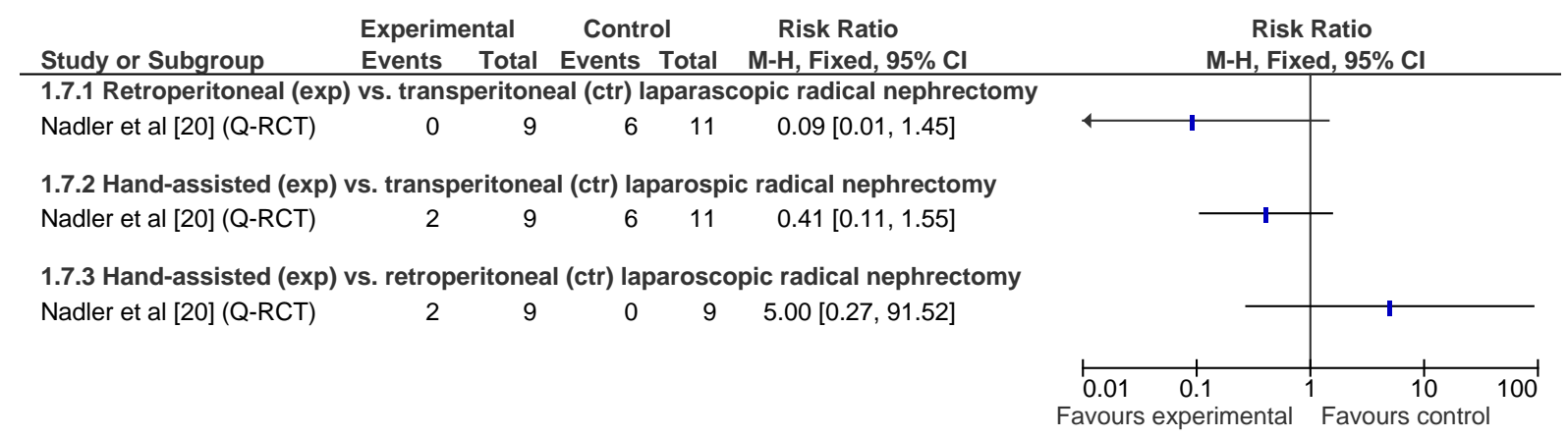


Figure 9: Time to nonstrenuous activity (days, mean, SD).

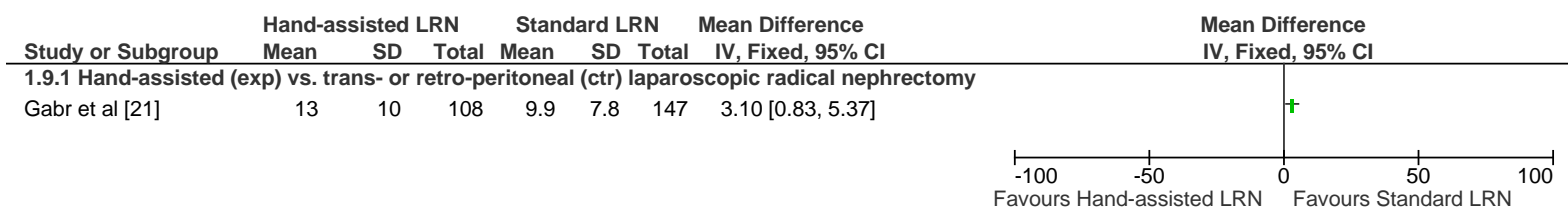


Appendix 1. Assessment of risk of bias*

\begin{tabular}{|c|c|c|c|c|c|c|c|c|c|}
\hline Study ID & Randomised? & $\begin{array}{l}\text { Adequate } \\
\text { sequence } \\
\text { generation? }\end{array}$ & $\begin{array}{l}\text { Allocation } \\
\text { concealment? }\end{array}$ & $\begin{array}{l}\text { Blinding for } \\
\text { Surgical } \\
\text { outcomes }\end{array}$ & $\begin{array}{l}\text { Blinding for } \\
\text { QoL } \\
\text { outcomes }\end{array}$ & $\begin{array}{l}\text { Incomplete } \\
\text { outcome } \\
\text { addressed for } \\
\text { surgical } \\
\text { outcomes? }\end{array}$ & $\begin{array}{l}\text { Incomplete } \\
\text { outcome } \\
\text { addressed for } \\
\text { QoL } \\
\text { outcomes? }\end{array}$ & $\begin{array}{l}\text { Free of } \\
\text { selective } \\
\text { outcome } \\
\text { reporting? }\end{array}$ & $\begin{array}{l}\text { Free of } \\
\text { other } \\
\text { bias? }\end{array}$ \\
\hline Aron 2008 [37] & No & No & No & Unclear & NA & Yes & NA & Yes & Unclear \\
\hline Blom 2009 [42] & Yes & Yes & Yes & Unclear & NA & Yes & NA & Yes & No \\
\hline Butler 1995 [28] & No & No & No & Unclear & NA & Yes & NA & Unclear & Unclear \\
\hline D'Armiento 1997 [25] & Yes & Yes & Unclear & NA & NA & NA & NA & Yes & Unclear \\
\hline Dash 2006 [32] & No & No & No & NA & NA & NA & NA & Unclear & Unclear \\
\hline Desai 2005a [18] & Yes & Yes & Yes & No & NA & Yes & NA & Yes & Unclear \\
\hline Desai 2005b [39] & No & No & No & none & NA & Unclear & NA & Unclear & No \\
\hline Gabr 2009 [21] & No & No & No & Unclear & NA & Unclear & NA & Unclear & Unclear \\
\hline Gill 2007 [33] & No & No & No & No & NA & No & NA & Unclear & Unclear \\
\hline Gong 2008 [35] & No & No & No & No & NA & No & NA & Unclear & Unclear \\
\hline Gratzke 2009 [16] & No & No & No & No & No & Yes & No & Yes & Unclear \\
\hline Hemal 2007 [17] & No & No & No & Unclear & NA & Yes & NA & Unclear & Unclear \\
\hline Hemal 2009 [22] & No & No & No & Unclear & NA & Yes & NA & Yes & Unclear \\
\hline Ko $2008[41]$ & No & No & No & No & NA & Yes & NA & Unclear & Unclear \\
\hline Lane 2010 [34] & No & No & No & NA & NA & NA & NA & No & Unclear \\
\hline Lee 2007 [29] & No & No & No & NA & NA & NA & NA & Unclear & Unclear \\
\hline Marszalek 2009 [36] & No & No & No & No & NA & Yes & NA & Yes & Yes \\
\hline $\begin{array}{l}\text { Nadler }(3 \mathrm{arm}) 2006 \\
\text { [20] }\end{array}$ & Yes & $\begin{array}{l}\text { No (quasi- } \\
\text { RCT) }\end{array}$ & No & No & NA & Yes & NA & Yes & Unclear \\
\hline Nambirajan 2004 [19] & Yes & Unclear & Unclear & Unclear & NA & Yes & NA & Unclear & Unclear \\
\hline O'Malley 2007 [40] & No & No & No & Unclear & NA & Yes & NA & Yes & Unclear \\
\hline Park 2009 [23] & No & No & No & Unclear & NA & Yes & NA & Unclear & Unclear \\
\hline Peng 2006 [15] & Yes & Unclear & Unclear & Unclear & Unclear & Unclear & Unclear & Unclear & Unclear \\
\hline Poulakis 2003 [27] & No & No & No & NA & NA & NA & NA & Unclear & Unclear \\
\hline Shekarriz 2002 [30] & No & No & No & Unclear & NA & Unclear & NA & Yes & Unclear \\
\hline Simmons 2009 [31] & No & No & No & NR & NA & NA & NA & Unclear & Unclear \\
\hline Soga 2008 [24] & No & No & No & Unclear & NA & Yes & NA & Unclear & Unclear \\
\hline Van Poppel 2007 [26] & Yes & Yes & Unclear & Unclear & NA & No & NA & Unclear & Unclear \\
\hline Wu 2010 [38] & No & No & No & Unclear & NA & Unclear & NA & Unclear & Unclear \\
\hline
\end{tabular}

NA = not applicable (surgical or QoL outcomes not reported)

* According to a recommended tool for RCT by the Cochrane Handbook [1 1] 